
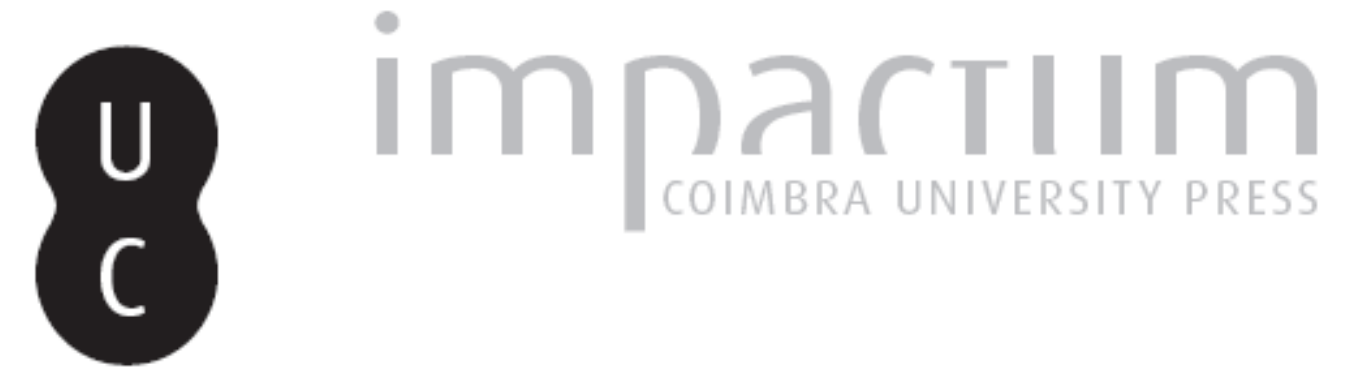

\title{
Dos objetivos da união bancária
}
Autor(es):
Quelhas, José Manuel
Publicado por: Faculdade de Direito da Universidade de Coimbra
URL persistente:
URI:http://hdl.handle.net/10316.2/30706
DOI:
DOI:http://dx.doi.org/10.14195/0870-4260_55_6
Accessed : $\quad$ 26-Apr-2023 15:38:14

A navegação consulta e descarregamento dos títulos inseridos nas Bibliotecas Digitais UC Digitalis, UC Pombalina e UC Impactum, pressupõem a aceitação plena e sem reservas dos Termos e Condições de Uso destas Bibliotecas Digitais, disponíveis em https://digitalis.uc.pt/pt-pt/termos.

Conforme exposto nos referidos Termos e Condições de Uso, o descarregamento de títulos de acesso restrito requer uma licença válida de autorização devendo o utilizador aceder ao(s) documento(s) a partir de um endereço de IP da instituição detentora da supramencionada licença.

Ao utilizador é apenas permitido o descarregamento para uso pessoal, pelo que o emprego do(s) título(s) descarregado(s) para outro fim, designadamente comercial, carece de autorização do respetivo autor ou editor da obra.

Na medida em que todas as obras da UC Digitalis se encontram protegidas pelo Código do Direito de Autor e Direitos Conexos e demais legislação aplicável, toda a cópia, parcial ou total, deste documento, nos casos em que é legalmente admitida, deverá conter ou fazer-se acompanhar por este aviso. 
VOLUME LV

$\begin{array}{llll}2 & 0 & 1 & 2\end{array}$

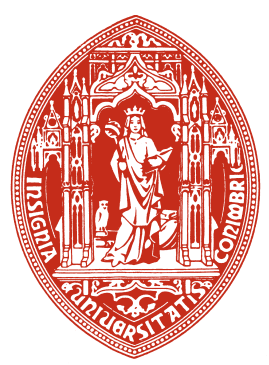




\section{DOS OBJECTIVOS DA UNIÃO BANCÁRIA}

\section{Introdução}

$\mathrm{Na}$ sequência da reforma do sistema financeiro prevista no «pacote legislativo» de 24 de Novembro de $2010^{12}$, a Comis-

1 O «pacote Legislativo» de 24 de Novembro de 2010 é composto pelos seguintes diplomas: Regulamento (UE) n. ${ }^{\circ}$ 1092/2010 do Parlamento Europeu e do Conselho, de 24.11.2010, relativo à supervisão macroprudencial do sistema financeiro na União Europeia e que cria o Comité Europeu do Risco Sistémico, pulicado no JO,L 331, de 15.12.2010, pp. 1-11; Regulamento (UE) n. ${ }^{\circ} 1093 / 2010$ do Parlamento Europeu e do Conselho, de 24.11.2010, que cria uma Autoridade Europeia de Supervisão (Autoridade Bancária Europeia), altera a Decisão n. ${ }^{\circ} 716 / 2009 / \mathrm{CE}$ e revoga a Decisão 2009/78/CE da Comissão, pulicado no JO, L 331, de 15.12.2010, pp. 12-47; Regulamento (UE) n. ${ }^{\circ}$ 1094/2010 do Parlamento Europeu e do Conselho, de 24.11.2010, que cria uma Autoridade Europeia de Supervisão (Autoridade Europeia dos Seguros e Pensões Complementares de Reforma), altera a Decisão n. ${ }^{\circ}$ 716/2009/CE e revoga a Decisão 2009/79/CE da Comissão, pulicado no JO, L 331, de 15.12.2010, pp. 48-83; Regulamento (UE) n. ${ }^{\circ} 1095 / 2010$ do Parlamento Europeu e do Conselho, de 24.11.2010, que cria uma Autoridade Europeia de Supervisão (Autoridade Europeia dos Valores Mobiliários e dos Mercados), altera a Decisão n. ${ }^{\circ}$ 716/2009/CE e revoga a Decisão 2009/77/CE da Comissão, pulicado no JO, L 331, de 15.12.2010, pp. 84-119; Regulamento (UE) n. ${ }^{\circ}$ 1096/2010 do Conselho, de 17.11.2010, que confere ao Banco Central Europeu atribuições específicas no que se refere ao funcionamento do Comité Europeu do Risco Sistémico, pulicado no JO, L 331, de 15.12.2010, pp. 162-164; Directiva 2010/78/UE, do Parlamento Europeu e do Conselho, de 24.11.2010, que altera as Directivas 98/26/ 
são Europeia apresentou ao Parlamento Europeu e ao Conselho, em 12 de Setembro de 2012, a Comunicação intitulada Roteiro para uma união bancária, que enquadrou nos seguintes termos:

"Concluir esta reforma do quadro regulamentar da UE é essencial, mas não será suficiente para enfrentar com êxito as vultuosas ameaças à estabilidade financeira em toda a União Económica e Monetária. São necessárias mais medidas, para enfrentar os riscos específicos na área do euro, onde a congregação das responsabilidades monetárias estimulou uma estreita integração económica e financeira e agravou a possibilidade de repercussões negativas além-fronteiras na eventualidade de crises bancárias, e para romper a ligação entre dívida soberana e dívida bancária, bem como o ciclo vicioso que levou a que fossem utilizados mais de 4,5 biliões de EUR dos contribuintes para resgatar bancos na UE. A coordenação entre as autoridades de supervisão é vital, mas a crise demonstrou que não basta uma simples coordenação, em especial no contexto de uma moeda única, e que é necessário tomar decisões em comum. Importa igualmente travar o risco crescente de fragmentação dos mercados bancários da UE, que mina significativamente o mercado de serviços financeiros e prejudica a transmissão efectiva da política monetária para a economia real em toda a área do euro" [cfr. ComisSÃo Europeia (2012a, p. 2)].

/CE, 2002/87/CE, 2003/6/CE, 2003/41/CE, 2003/71/CE, 2004/39/ /CE, 2004/109/CE, 2005/60/CE, 2006/48/CE, 2006/49/CE e 2009/ $/ 65 / \mathrm{CE}$, no que diz respeito às competências da Autoridade Europeia de Supervisão (Autoridade Bancária Europeia), da Autoridade Europeia de Supervisão (Autoridade Europeia dos Seguros e Pensões Complementares de Reforma) e da Autoridade Europeia de Supervisão (Autoridade Europeia dos Valores Mobiliários e dos Mercados), pulicado no JO, L 331, de 15.12.2010, pp. 120-161.

2 Sobre o sentido do "pacote legislativo" de 24 de Novembro de 2010, mormente sobre o alcance da criação do Comité Europeu do Risco Sistémico, cfr. Quelhas (2012a). 
De forma elucidativa, este excerto sublinha alguns dos objectivos primordiais da criação da união bancária, a saber: i) o reforço da resiliência do sistema financeiro; ii) a evitação do «efeito de contágio»; iii) a destrinça entre a evolução da dívida soberana e a evolução da dívida bancária; iv) a contenção do financiamento público das operações de bailout; $v$ ) o progresso da coordenação supervisora para a harmonização decisória; vi) o impedimento da fragmentação dos mercados financeiros.

\section{O reforço da resiliência do sistema financeiro}

O primeiro objectivo compreende-se à luz da crise financeira ${ }^{3}$ que assola os mercados internacionais desde 2007. No caso específico da União Europeia, a crise evidenciou a fragilidade genesíaca da União Económica e Monetária, que subalternizou a estabilidade do sistema financeiro à estabilidade dos preços, na condução da política monetária.

O cotejo da $1 .^{\text {a }}$ parte do n. ${ }^{\circ} 1$ e do $n .^{\circ} 2$ do art. ${ }^{\circ} 127 .^{\circ}$, do Tratado sobre o Funcionamento da União Europeia (TFUE), com os números 5 e 6 do mesmo artigo ilustra a referida subalternização. Com efeito, as duas primeiras disposições estatuem respectivamente que "1. O objectivo primordial do Sistema Europeu de Bancos Centrais [...] é a manutenção da estabilidade dos preços" e que "2. As atribuições fundamentais cometidas ao SEBC são: - a definição e execução da política monetária da União, - a realização de operações cambiais [...], - a detenção e gestão das reservas cambiais oficiais dos Estados-Membros, - a promoção do bom funcionamento dos

${ }^{3}$ Sobre o conceito, as etiologias, as formas de propagação e as consequências das crises financeiras, cfr. QuelHas (2012b), principalmente o "Capítulo 1. Das crises financeiras: contributo para a compreensão das crises financeiras". 
sistemas de pagamentos", ao passo que os dois últimos números prevêem seguidamente que " 5 . O SEBC contribuirá para a boa condução das políticas desenvolvidas pelas autoridades competentes no que se refere à supervisão prudencial das instituições de crédito e à estabilidade do sistema financeiro" e que "6. O Conselho, por meio de regulamentos adoptados de acordo com um processo legislativo especial, por unanimidade, e após consulta ao Parlamento Europeu e ao Banco Central Europeu, pode conferir a este último atribuições específicas no que diz respeito às políticas relativas à supervisão prudencial das instituições de crédito e outras instituições financeiras, com excepção das empresas de seguros”.

Nestes termos, o primeiro artigo do TFUE relativo à condução da política monetária hierarquiza os objectivos e as funções do SEBC. De sublinhar a diferença entre as redacções dos números 2, 5 e 6 do artigo 127. ${ }^{\circ}$ do TFUE. Enquanto o n. ${ }^{\circ} 2$ determina que "a definição e execução da política monetária da União” são funções inequívocas do SEBC obviamente subordinadas ao "objectivo primordial» da estabilidade dos preços - , o n. ${ }^{\circ} 5$ relega a supervisão prudencial das instituições de crédito e a estabilização do sistema financeiro para o domínio das «autoridades competentes», restringindo o papel do SEBC ao dever de contribuir para a boa condução das políticas desenvolvidas por essas autoridades, apesar de o n. 6 admitir que venham a ser conferidas ao SEBC "atribuições específicas no que diz respeito às políticas relativas à supervisão prudencial das instituições de crédito e outras instituições financeiras". Contudo, sublinhe-se, as referidas atribuições de supervisão prudencial só podem ser outorgadas ao SEBC através de regulamentos do Conselho adoptados por unanimidade.

Acresce que o Protocolo relativo aos Estatutos do Sistema Europeu de Bancos Centrais e do Banco Central Europeu, anexo ao Tratado da União Europeia (TUE) e ao TFUE, confirma 
a secundarização da actividade de supervisão prudencial do BCE, quando estatui, no art. ${ }^{\circ} 25 .^{\circ}$, n. $^{\circ} 1$, que "O BCE pode dar parecer e ser consultado pelo Conselho, pela Comissão e pelas autoridades competentes dos Estados-Membros sobre o âmbito e a aplicação da legislação da União relativa à supervisão prudencial das instituições de crédito e à estabilidade do sistema financeiro", apesar de o n. ${ }^{\circ} 2$ reafirmar a possibilidade de o Conselho conferir ao BCE o exercício de funções específicas nesta matéria. Em suma, quer o TFUE quer o Protocolo relativo aos Estatutos do SEBC e do BCE estabelecem uma linha divisória clara entre as atribuições de definição e execução da política monetária e de supervisão prudencial das instituições de crédito.

Ora, esta bipolarização de funções deve ser objecto de reflexão à luz das respostas da União Europeia e dos estados-membros à instabilidade decorrente da crise financeira que deflagrou em 2007. De notar que um dos motivos subjacentes à apresentação do «pacote de Novembro de 2010» foi precisamente o juízo negativo do legislador comunitário acerca da desarticulação entre as autoridades de supervisão nacionais e europeias.

De forma elucidativa, o "considerando 1» do Regulamento n. ${ }^{\circ}$ 1092/2010 asseverava que "A crise financeira revelou graves lacunas em matéria de supervisão financeira, que não conseguiu prever a evolução macroprudencial adversa nem impedir a acumulação de riscos excessivos no sistema financeiro", ao mesmo tempo que o «considerando 2» alertava para a discrepância entre a integração crescente dos mercados financeiros e a insuficiência na coordenação supervisora da União Europeia. Neste quadro, o «considerando 14» advogava a criação de um «Sistema Europeu de Supervisão Financeira» (SESF), que congregasse as autoridades supervisoras dos estados-membros e da União Europeia, mormente o Comité Europeu de Risco Sistémico, a Autoridade Bancária Europeia, 
a Autoridade Europeia dos Seguros e Pensões Complementares de Reforma e a Autoridade Europeia dos Valores Mobiliários e dos Mercados, as quais deveriam actuar em rede.

A actuação em rede não enseja apenas interligar as autoridades de supervisão dos estados-membros e da União Europeia, mas também conexionar os níveis de supervisão macro e microprudencial. De acordo com a terminologia do Regulamento n. ${ }^{\circ}$ 1092/2010, a supervisão macroprudencial do sistema financeiro da União Europeia competiria ao Comité Europeu de Risco Sistémico, ao passo que a supervisão microprudencial seria da responsabilidade da Autoridade Bancária Europeia, da Autoridade Europeia dos Seguros e Pensões Complementares de Reforma e da Autoridade Europeia dos Valores Mobiliários e dos Mercados.

O Regulamento n. ${ }^{\circ}$ 1092/2010 prevê ainda a instituição do Comité Conjunto das Autoridades Europeias de Supervisão, cujas criação e composição são sucessiva e reiteradamente disciplinadas pelos artigos $53 .^{\circ}$ a $57 .^{\circ}$ dos Regulamentos n. ${ }^{\circ} 1093 / 2010$, n. ${ }^{\circ} 1094 / 2010$ e n. ${ }^{\circ} 1095 / 2010$, com o intuito de garantir a coordenação e a coerência intersectorial entre as várias autoridades europeias de supervisão. Acresce que o Regulamento n. ${ }^{\circ}$ 1092/2010 também atribui ao Comité Europeu do Risco Sistémico o dever de cooperar com o Fundo Monetário Internacional, com o Banco de Pagamentos Internacionais, com o Conselho de Estabilidade Financeira e com o Grupo dos Vinte. Destarte, além da interligação entre as autoridades de supervisão dos estados-membros e da União Europeia e da coerência intersectorial entre as autoridades europeias de supervisão, o Comité Europeu de Risco Sistémico fica incumbido de assegurar a cooperação da União Europeia com as instituições financeiras internacionais.

De sublinhar que o "pacote legislativo» de Novembro de 2010 representa uma tentativa de compensar a aludida fragilidade genesíaca da União Económica e Monetária, 
aumentando a importância relativa da estabilidade financeira, a qual é classificada, no "considerando 1» do Regulamento

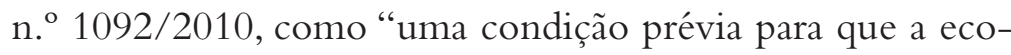
nomia real proporcione a criação de postos de trabalho, a concessão de crédito e o crescimento".

É neste sentido que se enquadram as duas propostas apresentadas, em 12 de Setembro de 2012, conjuntamente com o Roteiro para uma união bancária, a saber: a Proposta de Regulamento do Conselho que confere ao BCE atribuições específicas no que diz respeito às políticas relativas à supervisão prudencial das instituições de crédito ${ }^{4}$ e a Proposta de Regulamento do Parlamento Europeu $e$ do Conselho que altera o Regulamento (UE) n. ${ }^{\circ} 1093 / 2010$ que cria uma Autoridade Europeia de Supervisão (Autoridade Bancária Europeia) no que respeita à sua interacção com o Regulamento (UE) $n .^{\circ}$.../... do Conselho que confere ao Banco Central Europeu atribuições específicas no que diz respeito às políticas relativas à supervisão prudencial das instituições de crédito ${ }^{5}$.

Sublinhe-se que as duas propostas fundamentam expressamente a respectiva base jurídica no citado art. ${ }^{\circ} 127 .^{\circ}$, n. ${ }^{\circ}$ 6, do TFUE, ou seja, o Conselho pretende conferir ao BCE atribuições específicas relativas à supervisão prudencial das instituições de crédito. Deste modo, atenuar-se-ia a aludida secundarização da supervisão prudencial, por meio de regulamentos do Conselho, adoptados por unanimidade, com vista a aumentar a resiliência do sistema financeiro.

Aliás, sob a epígrafe objecto, o art. $^{\circ} 1 .^{\circ}$ da Proposta da Comissão Europeia (2012c) estatui que "O presente regulamento confere ao BCE atribuições específicas no que diz respeito às políticas relativas à supervisão prudencial das instituições de crédito, com vista a promover a segurança e a solidez das instituições de crédito e a estabilidade do sistema

\footnotetext{
${ }^{4}$ Cfr. Comissão Europeia (2012c).

5 Cfr. Comissão Europeia (2012d).
} 
financeiro, tendo em devida conta a unicidade e a integridade do mercado interno". Do mesmo modo, o "considerando 11» da Proposta da Comissão Europeia (2012d) elege o objectivo de "assegurar um nível elevado, eficaz e coerente de regulação e supervisão prudencial em toda a União Europeia que proteja a integridade, a eficiência e o bom funcionamento dos mercados financeiros e mantenha a estabilidade do sistema financeiro".

\section{A evitação do «efeito de contágio»}

O Roteiro para uma união bancária alerta expressamente para as consequências da propagação contagiosa das crises bancárias, nos seguintes termos:

"A integração financeira mundial e o mercado único da UE permitiram que, em alguns Estados-Membros, o sector bancário ultrapassasse muitas vezes o PIB nacional, resultando em instituições grandes de mais para falirem e grandes de mais para poderem ser salvas por meio dos dispositivos nacionais vigentes. Por outro lado, a experiência demonstra que até a falência de bancos relativamente pequenos pode causar danos sistémicos além-fronteiras. Acresce que as corridas aos depósitos em bancos situados noutros países podem enfraquecer drasticamente os sistemas bancários nacionais, prejudicando ainda mais a situação orçamental da entidade soberana e precipitando problemas de financiamento para ambas as partes" [cfr. Comissão Europeia (2012a, p. 8)]

Este excerto alerta para as causas e as consequências do «efeito de contágio» ${ }^{6}$, mormente para: a) a integração internacional dos mercados financeiros; $b$ ) o desfasamento entre os ritmos de crescimento dos sectores bancário e real da econo-

"Sobre o «efeito de contágio» cfr. Quelhas (2012b), sobretudo "3.2. «Efeito de contágio»: uma metáfora elucidativa ou um mito sem fundamento?". 
mia; c) a política do «too big to fail»; d) as disrupções económicas sistémicas das falências bancárias; e) a propagação além-fronteiras das "corridas bancárias»;f) o constrangimento ao financiamento dos sectores público e privado.

2.1. A integração dos mercados financeiros ${ }^{7}$ verificou-se, tanto a nível internacional quanto a nível europeu.

A nível internacional, a integração foi indissociável das tendências para a globalização, a desregulação, a desintermediação e a liberalização dos mercados financeiros, bem como da adopção do princípio da «banca universal», da proliferação de «novos produtos» e serviços financeiros e da profusão de novas tecnologias de informação e comunicação, no último quartel do século $\mathrm{XX}^{8}$.

A nível europeu, a concretização das sucessivas fases da União Económica e Monetária acentuou a integração dos mercados financeiros, por força da liberalização dos movimentos de capitais entre os estados-membros e entre estados-membros e países terceiros, a partir da 1. ${ }^{a}$ fase da UEM, do impedimento da monetarização dos défices públicos, da interdição de concessão de crédito pelo BCE ou pelos bancos centrais nacionais a favor de instituições comunitárias, autoridades públicas centrais, regionais e locais, organismos públicos ou empresas do sector público, bem como da proibição de acesso privilegiado ao crédito pelas mesmas entidades junto de instituições financeiras, a partir da 2. ${ }^{a}$ fase da UEM, e, por último, da introdução do euro, da condução das políticas monetária e cambial únicas e da consequente eliminação do

7 Sobre o papel da integração internacional dos mercados financeiros na deflagração das crises cfr. Quelhas (2012b), principalmente "1.2. Sobre a diversidade de contributos para a compreensão das crises financeiras".

${ }^{8}$ Sobre as causas, o significado e o impacto da «revolução financeira», no último quartel do séc. XX, cfr. QuelHas (1996). 
risco de variação das taxas de câmbio, entre os países participantes na $3 .^{a}$ fase da UEM ${ }^{9}$.

De notar que as proibições do TFUE ao endividamento dos estados-membros junto do BCE e à monetarização dos défices orçamentais direccionaram o mercado primário de dívida pública para as instituições de crédito e abriram novas oportunidades de negócio para os investidores institucionais ${ }^{10}$, bem como o surgimento de novos «produtos financeiros» de dívida pública.

Sublinhe-se que o impacto da integração financeira internacional sobre a estabilidade geral do sistema suscitou interpretações divergentes entre a comunidade dos economistas, das autoridades monetárias, dos reguladores e dos supervisores; por um lado, os membros da mainstream economics enfatizaram que a integração financeira propiciou a afectação eficiente de recursos financeiros escassos à escala internacional ${ }^{11}$; por outro lado, os elementos da corrente heterodoxa alertaram para os resultados desestabilizadores da liberalização dos fluxos de capitais, das taxas de juro e das taxas de câmbio, da desregulação dos mercados bancário, segurador e de valores mobiliários, da proliferação de operadores transnacionais e da oferta global de «novos produtos», inerentes à da integração financeira internacional ${ }^{12}$.

${ }^{9}$ Sobre o impacto da criação da União Económica e Monetária no processo de integração financeira europeu, nomeadamente no ensejo de formação de um mercado único de serviços financeiros na União Europeia, cfr. Allen e Song (2005), Bieling (2006), Lane (2008), Spiegel (2009a) e Spiegel (2009b).

10 Sobre a acção dos investidores institucionais, no contexto da criação da União Económica e Monetária, cfr. Davis (2003).

11 Cfr., inter alia, Schwartz (1998) e Bordo, Mizrach e Schwartz (1995).

12 Cfr., inter alia, Skidelsky (2000), Allen e Herring (2001), Grabel (2003a) e Grabel (2003b). 
2.2. O desfasamento entre os ritmos de crescimento dos sectores bancário e real da economia acentuou a «bancarização»" e a "financeirização» ${ }^{14}$ da actividade económica.

A «bancarização» da actividade económica não representa apenas o crescimento das operações passivas e activas dos bancos, mas também o alargamento do objecto negocial das instituições de crédito, bem como o exercício de operações bancárias por intermediários financeiros não bancários.

A intermediação bancária clássica - a canalização da poupança para o investimento, através da captação de depósitos e da concessão de crédito, bem como a disponibilização de liquidez aos depositantes - sofreu profundas mutações subjectivas e objectivas. Com efeito, a afirmação do princípio da «banca universal», a proliferação de operadores financeiros não bancários e a estruturação de "produtos complexos», que combinam diferentes activos subjacentes, quebram as fronteiras tradicionais entre os mercados monetários, cambiais, bancários, mobiliários e seguradores de diferentes países.

Destarte, as mutações subjectivas e objectivas propiciaram a propagação do "efeito de contágio» entre os diversos operadores e os vários sectores dos mercados financeiros. Aliás, a crescente indiferenciação dos sujeitos e a progressiva integração dos objectos esbateram as fronteiras regulamentares e negociais, que anteriormente estancavam a disseminação das dificuldades financeiras entre as diferentes instituições, sectores e países.

A «financeirização» da economia revela a disparidade entre o ritmo de crescimento do sector financeiro e o ritmo

13 Sobre o relevo da «bancarização» no processo de inovação financeira, cfr. QuelHas (1996, pp. 34-35).

14 Sobre o significado e o impacto da «financeirizaçao» da actividade económica, cfr. Grabel (1995), Grabel (2002), H.-J. Chang e Grabel (2004), Mota, Lopes e Antunes (2010) e Avelãs Nunes (2012). 
de crescimento do sector produtivo, o que exprime a quebra da natureza instrumental do primeiro sector e a consequente autonomização em relação ao segundo. Aliás, quanto maior for a disparidade entre os dois ritmos de crescimento, maior será o afastamento do sector financeiro em relação à base produtiva $^{15}$, o que significa a preponderância das operações especulativas imateriais sobre as actividades produtivas reais.

Acresce que a dissociação entre o sector financeiro e o sector produtivo, bem como a preponderância da actividade especulativa, extravasa as fronteiras nacionais, mormente através da primazia do «investimento indirecto» sobre o «investimento directo» estrangeiro ${ }^{16}$. Assim, os efeitos desestabilizadores sistémicos dos fluxos e refluxos dos «investimentos de carteira» disseminam-se à escala internacional ${ }^{17}$ e representam um dos desafios reguladores das autoridades europeias $^{18}$.

15 Sobre as consequências do desfasamento entre as taxas de crescimento dos sectores financeiro e real, cfr. Quelhas (2012b), sobretudo em "4.2.3. Da liberalização financeira, dos ganhos individuais de eficiência e das perdas colectivas de estabilidade".

16 Sobre a diferenciação entre "investimento directo» e «investimento indirecto» estrangeiro, cfr. QuelHas (2012b, nota 337). O primeiro corresponde à aplicação originária de capitais externos na criação, aquisição ou participação de empresas internas, ou seja, privilegia o investimento de longo prazo, ao passo que o segundo equivale ao «investimento de carteira», isto é, aos fluxos de capitais externos de curto prazo, tendencialmente especulativos e voláteis.

17 Sobre a disseminação dos efeitos desestabilizadores sistémicos, cfr. Quelhas (2012b), mormente em "3.2.4. Dos canais de transmissão do «efeito de contágio»".

18 Sobre a reacção das autoridades europeias, cfr. QuelHas (2012a), sobretudo em "4. Supervisão sistémica e efeito de contágio", onde se examinam as respostas do Regulamento que cria o Comité Europeu do Risco Sistémico, do Regulamento que cria a Autoridade Bancária Europeia, do Regulamento que cria a Autoridade Europeia dos Seguros e Pensões Complementares de Reforma e do Regulamento que cria a Autoridade Europeia dos Valores Mobiliá- 
2.3. A política do «too big to fail» ${ }^{19}{ }^{20}$ pressupõe que a falência de uma instituição de crédito de grande dimensão desencadeie consequências disruptivas sistémicas, que devam ser impedidas ab initio. Tal justificaria a intervenção salvífica das autoridades e, inclusive, o financiamento público das operações de bailout.

O impacto negativo da falência de um banco não se circunscreve aos seus accionistas e aos seus credores, mas propaga-se de forma directa ou indirecta por toda a actividade económica. De forma directa, pelo incumprimento das operações bancárias passivas e pela impossibilidade superveniente das operações bancárias activas, que obstroem a canalização da poupança para o investimento e que indisponibilizam a liquidez. De forma indirecta, pela incapacidade de os clientes atingidos solverem atempadamente os seus compromissos, o que dissemina as dificuldades ao longo das cadeias de crédito, gerando efeitos cumulativos por força da desmultiplicação do crédito e da secagem da liquidez. Mas, além da contracção directa ou indirecta do crédito e da liquidez, a possibilidade de falência de um banco pode suscitar "corridas bancárias» contagiosas junto de outros bancos ${ }^{21}$, desencadeando levanta-

rios e dos Mercados. Acresce que o Regulamento n. ${ }^{\circ}$ 1092/2010 atribui ao Comité Europeu de Risco Sistémico o dever de cooperar com o Fundo Monetário Internacional, com o Conselho de Estabilidade Financeira e com os membros do Grupo dos Vinte no combate ao «efeito de contágio».

19 Sobre o significado da política do «too big to fail», cfr. QuelHas (2012b), principalmente “3.2.5.4. O «efeito de contágio» e a rede de contratação financeira”, bem como as notas 274 e 328.

20 Sobre a controvérsia em torno da regra do «too big to fail», cfr. Angbazo e Saunders (1997), Freixas e Rochet (1998), Bordo e Schwartz (1999), Freixas (1999), Spiegel e Yamori (2000), Guenther (2001), Kaufman e Seelig (2001), Furfine (2002), Kane (2002), Kaufman (2003a) e Kaufman (2003b).

21 Acerca dos vários modelos de «corridas bancárias», cfr. QuelHas (2012b), principalmente em “1.1.3.1. Os modelos originais de corridas 
mentos em massa e restringindo a capacidade creditícia geral do sistema bancário ${ }^{22}$. Neste cenário, as autoridades públicas deveriam intervir antes da falência de um banco, logo que este apresentasse sinais de insolvência ou de iliquidez ${ }^{2324}$.

À escala da União Europeia, a política do «too big to fail» já está consagrada no "pacote legislativo de Novembro de 2010", nomeadamente nos Regulamentos n. ${ }^{\circ}$ 1092/2010 e n. ${ }^{\circ} 1093 / 2010^{25}$.

bancárias" e em "1.1.3.2. A extensão dos modelos originais de corridas bancárias". Sobre os modelos originais de "corridas bancárias", cfr. Diamond e Dybvig (1983), Waldo (1985), Gorton (1985), Jacklin e Bhattacharya (1988), Chari e Jagannathan (1988), Calomiris e Kahn (1991), Carletti (1999), Diamond e Rajan (1999a), Diamond e Rajan (1999b), Diamond e Rajan (2000) e Diamond e Rajan (2002); sobre a extensão dos modelos originais de "corridas bancárias", cfr. GARBER e Grilli (1988), Smith (1991), De Bandt (1995) e Temzelides (1997).

${ }^{22}$ Sobre a correlação entre o "efeito de contágio» e as «corridas bancárias», cfr. Quelhas (2012b), sobretudo em "3.2.5.1. O «efeito de contágio» e a propagação sistémica das corridas bancárias".

${ }^{23}$ Sobre a diferenciação entre insolvência e iliquidez, cfr. RADELET e Sachs (1998a, p. 5), Cardim de Carvalho (2002, p. 3), Goodhart e Illing (2002, p. 16) e QuelHas (2012b), especialmente em «4.1.2. Das dificuldades metodológicas de predição de crises».

${ }^{24}$ Sobre a diferenciação entre "episódios de insolvência bancária» e "crises bancárias», cfr. Caprio Jr. e Klingebiel (1996a) e Caprio Jr. e KLingebiel (1996b), para quem os "episódios de insolvência» não teriam consequências sistémicas, ao passo que as «crises bancárias» teriam sempre carácter sistémico, isto é, propagar-se-iam destrutivamente por todo o sistema. Porém, um "episódio de insolvência» poderia degenerar numa "crise bancária», por força do "efeito de contágio». Neste sentido, Lindgren, GARCIA e SAAL (1996) justificam a intervenção atempada das autoridades públicas no intuito de travarem a disseminação do «efeito de contágio»e de preservarem a estabilidade geral do sistema financeiro.

25 O «considerando 10» do Regulamento n. ${ }^{\circ}$ 1092/2010 atribui ao Comité Europeu de Risco Sistémico a missão de "monitorizar e avaliar o risco sistémico em períodos normais, com o objectivo de atenuar a exposição do sistema ao risco de falência de componentes sistémicos e 
2.4. As disrupções económicas sistémicas não resultam apenas da falência de grandes bancos, mas podem inclusive derivar da insolvência ou da falta de liquidez de instituições de crédito de menor dimensão, através da «capacidade amplificadora» do sistema financeiro ${ }^{26}$ e do desencadeamento de ataques especulativos ${ }^{27}$.

aumentar a resistência do sistema financeiro aos choques", explicitando o "considerando 9» que "os critérios fundamentais para ajudar a identificar a importância sistémica dos mercados e das instituições são a dimensão (o volume de serviços financeiros prestados pela componente individual do sistema financeiro), a substituibilidade (a capacidade de outros componentes do sistema proporcionarem os mesmos serviços em caso de falência) e a interconectividade (vínculos com outros componentes do sistema)", ou seja, a dimensão de um banco é expressamente reconhecida como critério relevante para o apuramento dos efeitos sistémicos da sua falência. No mesmo sentido, o art. ${ }^{\circ} 27 .^{\circ}$, n..$^{\circ} 1$, do Regulamento n. ${ }^{\circ}$ 1093/2010 estipula “A Autoridade [Bancária Europeia] contribui para o desenvolvimento de métodos para a resolução de situações de falência de instituições financeiras, especialmente as que possam apresentar um risco sistémico, em moldes que evitem o contágio e permitam a liquidação da sua actividade de uma forma ordenada e atempada, incluindo, se for caso disso, mecanismos de financiamento coerentes e sólidos".

26 Sobre o significado de "capacidade amplificadora» do sistema financeiro, cfr. R. Chang e Velasco (1998a, pp. 25-28).

27 Sobre os modelos de ataques especulativos, cfr. QuelHas (2012b), mormente em "1.1.8. Os modelos de ataques especulativos", onde se examinam sucessivamente os modelos de "primeira geração", de "segunda geração» e de «terceira geração», bem como as perspectivas de «novas gerações» de modelos.

Os modelos de "primeira geração» reportam aos trabalhos sobre crises cambiais de Krugman (1979) e de Flood e Garber (1984), que explicam os ataques especulativos sobre divisas a partir da inconsistência entre as políticas económicas internas, nomeadamente entre o financiamento monetário do défice orçamental e a fixação de taxas de câmbio. Nesta geração de modelos, os ataques são respostas racionais e previsíveis dos especuladores e assentam em fundamentos económicos reais.

Os modelos de «segunda geração» - cfr. Krugman (1999), ObstFeld (1991), Obstfeld (1994), Obstfeld (1996), Drazen e Masson (1994), 
A «capacidade amplificadora» do sistema financeiro alude à hipótese de choques económicos exógenos de pequena dimensão causarem degenerescências económicas endógenas de grande dimensão, por força da imprevisibilidade reactiva dos operadores. Por exemplo, um pequeno choque exógeno pode disseminar o pânico entre os depositantes e os investidores, que correrão para os levantamentos e que liquidarão prematuramente os activos, provocando a contracção múltipla dos depósitos bancários e a quebra dos preços, bem como a desmultiplicação do crédito e a retracção da actividade económica geral.

O desencadeamento de ataques especulativos introduz conceitos estritamente não financeiros na compreensão das

Masson (1995), Ozkan e Sutherland (1995) e Ozkan e Sutherland (1998) - introduzem variáveis comportamentais na interpretação dos ataques especulativos, que podem ser desencadeados independentemente da evolução dos fundamentos económicos reais. Nesta geração de modelos, sobressaem os conceitos de herd behaviour, de self-fulfilling crises, de self-confirming optimism e de self-confirming pessimism, que aludem a dinâmicas comportamentais autofágicas, capazes de gerarem espirais eufóricas de confiança ou espirais disfóricas de pessimismo.

A referência aos modelos de «terceira geração» reporta-se a KRUGMAN (1999a), que os subdivide em duas linhas de investigação: a primeira centrada nos trabalhos de Krugman (1998) e Corsetti, Pesenti e Roubini (1998); a segunda em torno dos trabalhos de Radelet e Sachs (1998b), R. Chang e Velasco (1998a) e R. Chang e Velasco (1998b). A primeira linha de investigação interliga as crises cambiais com as crises monetárias e financeiras e justifica a deflagração de ataques especulativos a partir de espirais depressivas auto-sustentáveis e contagiosas, desencadeadas em reacção a situações de «risco moral». A segunda linha de investigação explica os ataques especulativos a partir de espirais autosustentáveis de perda de confiança, que geram a liquidação prematura de activos.

Por último, Krugman (2003) alude a «novas gerações» de modelos, que deslocam o centro dos ataques especulativos dos activos cambiais para os activos financeiros, ao mesmo tempo que sobrevalorizam a formação de espirais deflacionistas auto-sustentáveis a partir da perda de confiança dos operadores. 
relações de crédito, nomeadamente os de animal spirits ${ }^{28}$, de herd behaviour ${ }^{29}$, de self-fulfilling prophecies ${ }^{30}$ e de moral hazard ${ }^{31}$.

28 A expressão animal spirits foi introduzida por Keynes (1973, pp. 161-162) e enfatiza a importância de factores subjectivos, não racionais e não quantificáveis, na formação das decisões de investimento. Sobre o relevo do conceito de animal spirits para a compreensão do significado de incerteza nos mercados financeiros, cfr. QuelHAs (2012b), sobretudo em "2.1.4.1. A "incerteza verdadeira".

${ }^{29}$ A análise da influência do "comportamento de grupo» na tomada de decisões individuais reporta a KEYNES (1973, pp. 155-156), que criou imagens indeléveis acerca da formação das expectativas dos investidores em mercados organizados de valores mobiliários, mormente as metáforas do "Beauty Contest» e dos jogos de Snap, de Old Maid e de Musical Chairs.

Sobre o relevo do herd behaviour para a compreensão das crises financeiras, cfr. Scharfstein e Stein (1990), Devenow e Welch (1996), Bikhchandani e Sharma (2000), Shiller (1993), Shiller (1995), Shiller (2001), Shiller (2003) e Quelhas (2012b), principalmente em "1.1.7.4. O papel do herd behaviour".

Sublinhe-se, ainda, que a importância da psicologia comportamental para a compreensão do funcionamento dos mercados foi objecto de múltiplos estudos, que realçaram a interdisciplinaridade entre a economia e a psicologia - cfr., inter alia, KAHNEMAN (2002), KAHNEMAN, KNETSCH e Thaler (1987), Kahneman, Knetsch e Thaler (2002), Kahneman, Ritov e Schkade (2002), Kahneman e Tversky (2002a), Kahneman e Tversky (2002b) e TVErSky e KahNEMAN (2002).

30 As «profecias auto-sustentáveis» representam um dos factores deflagradores das "corridas bancárias». Com efeito, num regime de reservas fraccionadas, se alguns depositantes temerem que outros depositantes venham a mobilizar antecipadamente os respectivos depósitos, podem os primeiros precipitar também o levantamento dos seus depósitos, independentemente dos fundamentos económicos reais ou da solvabilidade do depositário, exaurindo as reservas do banco e forçando-o a liquidar prematuramente os seus activos. Destarte, a aplicação da regra do first-come-first-served acelera as corridas aos levantamentos bancários, ou seja, a profecia temorosa inicial auto-realiza-se.

Sobre as self-fulfilling prophecies, cfr. FitzgibBons (1990), Krugman (1996), Obstfeld (1996), Jeanne (1997), Cole e Kehoe (1998), OzKan e Sutherland (1998), Krugman (1999), Masson (1999), Freixas, Parigi e Rochet (2000), Rosser Jr. (2000), De Bandt e Hartmann (2002) e GoOdhart e Illing (2002).

31 Sobre o relevo do conceito de moral hazard para a compreensão das crises financeiras, cfr. Quelhas (2012b), mormente em “3.1.3. Visão 
2.5. A preocupação com a propagação além-fronteiras das «corridas bancárias» perpassa o "pacote legislativo» de 24 de Novembro de 2010, bem como as propostas de 12 de Setembro de 2012, apresentadas conjuntamente com o Roteiro para uma união bancária.

O Regulamento que cria o Comité Europeu do Risco Sistémico considera a estabilidade do sistema financeiro uma condição sine qua non para o funcionamento regular do mercado interno ${ }^{32}$, ao mesmo tempo que sublinha a interconexão crescente entre as instituições e os mercados financeiros dos diferentes estados-membros. Esta interconexão faz com que a crise de um banco - mesmo de pequena dimensão - não se circunscreva às fronteiras nacionais e se propague contagiosamente pelos restantes países.

intermédia: da disrupção dos fluxos de informação como fundamento do conceito de risco sistémico" e em “3.2.5.5. O "efeito de contágio» e o trade-off entre o «risco moral» e o risco sistémico".

O trade-off entre o «risco moral» e o risco sistémico alude ao comportamento das autoridades monetárias perante a ameaça de falência de uma instituição de crédito, maxime de um banco de grande dimensão. Num cenário, se as autoridades percepcionarem um banco como «demasiado grande para falir», engendrarão operações de salvamento, com o intuito de conterem o risco sistémico; porém, os restantes banqueiros interpretarão o bailout como o estabelecimento de uma rede pública de segurança, o que diminuirá os critérios individuais de prudência e exponenciará o «risco moral». Noutro cenário, embora as autoridades percepcionem um banco como «demasiado grande para falir», não engendrarão operações de salvamento, com o intuito de evitarem o risco moral; porém, os depositantes de outros bancos interpretarão a falência do big bank como sinal de fragilidade dos seus depositários, o que precipitará corridas individuais aos levantamentos e exponenciará o risco sistémico.

Acerca do trade-off entre «risco moral» e risco sistémico, cfr. FreIXAS e Rochet (1998), Freixas (1999) e Aghion, Bolton e Dewatripont (2000). Sublinhe-se que Freixas e Rochet (1998, pp. 286-287) e Freixas (1999) advogam que as decisões de bailout dos bancos centrais sejam norteadas por uma «ambiguidade construtiva», no intuito de mitigar o "risco moral».

32 Cfr. os «considerandos» $10,27,30$ e 31 , bem como os artigos $2 .^{\circ}$, al. c), e 3. ${ }^{\circ}, \mathrm{n} .^{\circ} 1$, do Regulamento n. ${ }^{\circ} 1092 / 2010$. 
Deste modo, a salvaguarda do mercado interno exige que o Comité Europeu do Risco Sistémico actue a montante e a jusante da deflagração das crises bancárias. A montante, através da supervisão macroprudencial do sistema financeiro, da coordenação das autoridades europeias de supervisão microprudencial e da cooperação com as autoridades nacionais, no intuito de evitar a deflagração de crises bancárias; a jusante, através da adopção de respostas integradas, que restaurem a confiança entre os operadores transfronteiriços, que actuam no mercado comum de serviços financeiros.

Por seu turno, o Regulamento que cria a Autoridade Bancária Europeia reitera a conexão entre a estabilidade do sistema financeiro e o funcionamento regular do mercado interno ${ }^{33}$. De um modo particular, o Regulamento n. ${ }^{\circ}$ 1093/2010 sustenta que o aprofundamento e a integração dos mercados bancários dos estados-membros aumentam a capacidade de financiamento da economia real e diversificam os riscos dos operadores, desde que a estabilidade sistémica não seja posta em causa.

Destarte, a Autoridade Bancária Europeia enseja responder ao trade-off entre eficiência e estabilidade, inerente ao mercado único de serviços bancários. Com efeito, as operações transfronteiriças propiciam ganhos de escala e aumentam as alternativas à disposição dos depositantes para a aplicação de poupanças e dos investidores para a captação de financiamentos, além de, tendencialmente, diminuírem os spreads entre as taxas bancárias activas e passivas. Porém, as operações transfronteiriças também facilitam a propagação contagiosa de crises entre bancos e clientes bancários passivos e activos de diferentes estados-membros ${ }^{34}$.

33 Cfr. os «considerandos» $5,7,11,15,16,17$ e 66 , bem como os artigos $1 .^{\circ}$, n. ${ }^{\circ} 5$, al. a), 9..$^{\circ}$ n..$^{\circ} 1$, e $22 .^{\circ},{ }^{\circ}{ }^{\circ} 1$, al. b), do Regulamento n. ${ }^{\circ} 1093 / 2010$.

34 Neste sentido, o Regulamento que cria a Autoridade Bancária Europeia introduz o conceito de "risco transfronteiriço», que define nos seguintes termos: "O risco transfronteiriço compreende todos os riscos causados por 
O compromisso entre a eficiência e a estabilidade subjaz igualmente ao Roteiro para uma união bancária, apresentado em 12 de Setembro de 2012, que selecciona três domínios de actuação prioritária ${ }^{35}:$ i) a criação do Mecanismo Único de Supervisão $(\mathrm{MUS})^{36}$; ii) a harmonização do sistema comum

desequilíbrios económicos ou insolvências na totalidade ou em partes do território da União, que possam produzir consequências negativas significativas para as transacções entre os operadores económicos de dois ou mais Estados-Membros, para o funcionamento do mercado interno ou para as finanças públicas da União ou de qualquer um dos seus Estados-Membros” [cfr. o "considerando 16» do Regulamento n. ${ }^{\circ}$ 1093/2010]. Refira-se que este conceito é comum aos Regulamentos que criam a Autoridade Europeia dos Seguros e Pensões Complementares de Reforma e a Autoridade Europeia dos Valores Mobiliários e dos Mercados - cfr., respectivamente, o «considerando 15» do Regulamento n. ${ }^{\circ}$ 1094/2010 e o "considerando 16» do Regulamento n. ${ }^{\circ} .1095 / 2010$.

35 Cfr. Comissão Europeia (2012a, pp. 3-4).

${ }^{36} \mathrm{Na}$ "exposição dos motivos» da Proposta de Regulamento do Consetho que confere ao BCE atribuições específicas no que diz respeito às políticas relativas à supervisão prudencial das instituições de crédito, sustenta-se: "A Comissão lançou [...] um apelo, em Maio de 2012, e como parte de uma visão a mais longo prazo da integração económica e orçamental, no sentido de uma união bancária que permita restabelecer a confiança nos bancos e no euro. Um dos elementos cruciais dessa união bancária deverá ser um Mecanismo Único de Supervisão (MUS) com supervisão directa dos bancos, para aplicar as normas prudenciais de forma rigorosa e imparcial e efectuar uma supervisão eficaz dos mercados bancários transfronteiras. Ao assegurar-se que a supervisão bancária em toda a área do euro se pauta por normas comuns de elevado nível contribui-se para construir a confiança necessária entre Estados-Membros, o que constitui uma condição indispensável para a introdução de quaisquer mecanismos de protecção comuns" [cfr. Comissão Europeia (2012c, p. 2)]. De sublinhar que a criação do MUS enseja "restabelecer a confiança nos bancos e no euro" e é indissociável do processo de "integração económica e orçamental", ou seja, reafirma-se a estabilidade do sistema bancário como condição sine qua non para a normalidade do mercado interno, ao mesmo tempo que se insere a instituição da união bancária no processo mais ambicioso de integração económica e orçamental. 
de garantias de depósitos ${ }^{37}$; iii) a instituição de um quadro integrado de gestão de crises $^{38}$.

37 A Directiva 2009/14/CE do Parlamento Europeu e do Conselho, de 11 de Março de 2009, que altera a Directiva 94/19/CE relativa aos sistemas de garantia de depósitos, no que respeita ao nível de cobertura e ao prazo de reembolso, impeliu os Estados-membros a transporem para as ordens jurídicas internas, até 31 de Dezembro de 2010, a obrigação de elevarem os sistemas de garantias de depósitos nacionais para 100000 euros por depositante e por instituição.

Já em 12 de Julho de 2010, a Comissão Europeia propôs medidas suplementares para o reforço da protecção dos depositantes, no que concerne ao encurtamento dos prazos de reembolso e à normalização da informação sobre a aplicação dos sistemas de garantias de depósitos nacionais à disposição de todos os clientes bancários, independentemente do estado-membro de residência - cfr. Comissão Europeia (2010c).

O texto de «Exposição de Motivos» da Proposta de Directiva, de 12 de Julho de 2010, privilegiou expressamente as seguintes opções: "Simplificar e harmonizar o âmbito da cobertura; Reduzir o prazo de reembolso para sete dias; Pôr termo à prática que consiste na compensação dos débitos contra os créditos dos depositantes; Introduzir uma minuta de informação a visar pelos depositantes e uma referência obrigatória aos SGD nos extractos de conta e na publicidade; Harmonizar a abordagem do financiamento dos SGD; Fixar um nível-alvo para os fundos dos SGD; Fixar a proporção das contribuições ex ante e ex post dos bancos para os SGD; Introduzir elementos baseados no cálculo das contribuições dos bancos para os SGD; Limitar a utilização dos fundos dos SGD para fins mais alargados de resolução de crises num banco, em benefício de todos os seus credores; Fazer com que o SGD do país de acolhimento funcione como ponto único de contacto para os depositantes em sucursais noutro Estado-Membro" - cfr. Comissão Europeia (2010c, pp. 4-5).

De sublinhar, sobretudo, a redução do prazo de reembolso dos depositantes para 7 dias, em caso de incumprimento do depositário, e a comunicabilidade entre os SGD nacionais, mormente entre o SGD do país de residência do depositante e o SGD do estado-membro da sede do depositário, bem como a harmonização do âmbito de cobertura dos SGD nacionais, a normalização da informação sobre os SGD à escala europeia e a reestruturação da forma de financiamento dos SGD, combinando fundos ex ante, contribuições ex post e «empréstimos mútuos». 
Em suma, a adopção destas medidas enseja aumentar a protecção dos depositantes, favorecer o mercado único de serviços bancários e garantir a estabilidade sistémica, travando a deflagração de «corridas bancárias» contagiosas.

38 Em 6 de Junho de 2012, foi apresentada a Proposta de Directiva do Parlamento Europeu e do Conselho que estabelece um enquadramento para a recuperação e resolução de instituições de crédito e empresas de investimento - $\mathrm{cfr}$. Comissão Europeia (2012b).

O texto da «Exposição dos Motivos» justifica a apresentação desta Proposta de Directiva, nos seguintes termos: "Os bancos e as empresas de investimento (a seguir designados «instituições») prestam serviços essenciais aos cidadãos, às empresas e à economia em geral (por exemplo aceitando depósitos, concedendo crédito e assegurando o funcionamento dos sistemas de pagamento). Funcionam em grande medida com base numa relação de confiança e podem rapidamente deixar de ser viáveis se os seus clientes e contrapartes perderem essa confiança na sua capacidade para cumprirem as suas obrigações. Em caso de colapso, os bancos deveriam ser liquidados de acordo com os procedimentos normais de insolvência. No entanto, o grau de interdependência entre as instituições resulta num risco de crise sistémica, em que os problemas de um banco podem repercutir-se através do sistema no seu todo. Tendo em conta esse risco sistémico e a importante função económica das instituições, os procedimentos normais de insolvência poderão não ser apropriados em determinados casos e a ausência de instrumentos que permitam uma gestão efectiva das instituições em crise resultou demasiadas vezes na necessidade de utilizar fundos públicos para repor a confiança, mesmo em pequenas instituições, de modo a evitar que, por efeito de dominó, as crises numa instituição resultassem em prejuízos sérios para a economia real" [cfr. CoMissão Europeia (2012b, p. 5)].

Este excerto revela algumas das especificidades do negócio bancário, mormente a da imaterialidade do seu activo subjacente essencial - a confiança -, cuja inconstância caracteriza o comportamento dos depositantes e dos depositários. Destarte, a canalização da poupança para o investimento fica sujeita à volubilidade da confiança dos operadores, ou seja, a volatilidade não se circunscreve à esfera financeira, mas repercute-se, de forma amplificada, na actividade produtiva real.

A referida amplificação decorre do «efeito dominó», intrínseco às relações de crédito bancário, onde a quebra de um dos elos se repercute 
aceleradamente sobre os depositantes e os depositários. Esta aceleração suscita «corridas bancárias» contagiosas e precipita a liquidação prematura de activos pelos depositários, com vista ao cumprimento dos pedidos de mobilização antecipada por parte dos depositantes.

As consequências disruptivas sistémicas das crises bancárias serviram de justificação reiterada para o financiamento público de operações de resgate, bem como para a consagração de regimes legais específicos sobre insolvências de instituições de crédito, diferentes das regras sobre falências aplicáveis às restantes actividades económicas.

É neste contexto que se insere a Proposta da Comissão Europeia, de 6 de Junho de 2012, cujo conteúdo prossegue o "pacote legislativo», de 24 de Novembro de 2010, e prepara o Roteiro para uma união bancária, de 12 de Setembro de 2012.

Sublinhe-se que a Proposta, de 6 de Junho de 2012, estabelece patamares gradativos de intervenção, por parte das autoridades públicas, diferenciando entre as «medidas de preparação e prevenção", as «medidas de intervenção precoce» e as "medidas de resolução».

As primeiras cumprem objectivos profilácticos e ensejam a elaboração de planos de contingência, que planeiem as acções de recuperação a adoptar pelos bancos, em caso de agravamento da situação financeira interna ou de deterioração das condições negociais gerais.

As segundas intentam a monitorização permanente da situação financeira e das condições negociais dos bancos, com o objectivo de percepcionarem precocemente sinais de alerta, de forma a corrigirem, de forma atempada, as trajectórias desviantes. A Proposta de Directiva prevê a adopção de projectos de recuperação de activos, de programas de reestruturação da dívida e de planos de recapitalização, bem como a nomeação provisória de gestores especiais pelas autoridades de supervisão.

As terceiras arquitectam planos de resolução de bancos insolventes, com vista à minoração do impacto sistémico, salvaguardando os interesses dos depositantes e dos contribuintes. A Proposta de Directiva prevê a adopção de procedimentos harmonizados, bem como a aplicação de instrumentos comuns de resolução bancária, à escala da União Europeia, mormente de regras sobre o saneamento dos balanços, a segregação e a autonomização de grupos de activos em função da qualidade, a liquidação de activos inviáveis, a criação e a posterior venda de «bancos de transição», as operações de resgate interno por recapitalização accionista ou por conversão de créditos em acções (bail-in) e de resgate externo por autoridades públicas (bailout). 
2.6. Uma das consequências do «efeito de contágio» é o constrangimento ao financiamento dos sectores público e privado $^{39}$. Com efeito, a deflagração de uma «corrida bancária» diminui a capacidade creditícia dos depositários, que racionam a concessão de empréstimos, tanto a mutuários públicos quanto a privados. Porém, por força da integração crescente dos mercados bancários, a constrição ao crédito não se circunscreve às fronteiras nacionais, antes se propaga pelas restantes praças financeiras onde os prestamistas operam.

Neste cenário, o constrangimento ao financiamento resulta da recomposição transfronteiriça das carteiras dos ban$\cos ^{40}$, ou seja, as instituições de crédito reduzem a concessão de empréstimos junto de mutuários públicos e privados de um estado por força da mobilização antecipada de depósitos noutro estado.

Destarte, a constrição ao financiamento dos sectores público e privado num estado pode resultar de choques idios-

Sublinhe-se que a Proposta de Directiva enfatiza a importância da cooperação entre as autoridades monetárias e supervisoras dos diferentes estados-membros e destas com a Autoridade Bancária Europeia, na aplicação das «medidas de preparação e prevenção», das "medidas de intervenção precoce» e das «medidas de resolução», principalmente no que concerne aos bancos que realizam operações transfronteiriças.

Um dos pontos sensíveis da Proposta de Directiva diz respeito ao custeamento das «medidas de resolução», nomeadamente à contenção do financiamento público dos bailouts. Neste sentido, a Proposta prevê a criação de "fundos de resolução», que sejam financiados pelos bancos, na proporção dos seus passivos, e que fiquem consignados ao expurgo sistémico das instituições de crédito.

39 Sobre a relação entre o «efeito de contágio» e o constrangimento ao financiamento, cfr. QuelHas (2012b), principalmente em “3.2.4.2. O canal financeiro" e "3.2.5.9. O «efeito de contágio», a informação assimétrica nos mercados financeiros e o constrangimento ao financiamento".

40 Sobre a recomposição internacional das carteiras de crédito, cfr. Quelhas (2012b), sobretudo em “3.2.5.10. O «efeito de contágio» e a recomposição internacional de carteiras". 
sincráticos noutro estado, por força da partilha de credores comuns, independentemente da intensidade das relações económicas reais ${ }^{41}{ }^{42}$.

\section{A destrinça entre a evolução da dívida soberana e a evolução da dívida bancária}

O «considerando 5» da Proposta de Regulamento do Conselho que confere ao BCE atribuições específicas no que diz respeito às políticas relativas à supervisão prudencial das instituições de crédito sustenta:

"A solidez das instituições de crédito está em muitos casos ainda estreitamente ligada ao Estado-Membro em que se encontram estabelecidas. A incerteza que rodeia a sustentabilidade da dívida pública, as perspectivas de crescimento económico e a viabilidade das instituições de crédito têm vindo a criar ciclos de retroacção negativa, que se alimentam mutuamente. Tal pode pôr em risco a viabilidade de certas instituições de crédito, bem como a estabilidade do sistema financeiro, sendo ainda susceptível de impor uma carga pesada sobre a situação, já delicada, das finanças públicas nos Estados-Membros em causa. Este problema levanta riscos específicos

${ }^{41}$ Sobre a transmissão contagiosa de choques idiossincráticas entre mercados de diferentes países, cfr. Kodres e Pritsker (2002) e YuAN (2005).

42 Kaminsky e Reinhart (2000) explicam a transmissão do «efeito de contágio» através do "canal dos credores bancários comuns», sustentando que a deflagração de uma crise financeira, no país contagiante, suscita a recomposição das carteiras de crédito dos bancos comuns, nos países contagiados. Nestes termos, o inadimplemento das obrigações, por mutuários do país contagiante, diminui a concessão de crédito a mutuários dos países contagiados, por parte de mutuantes comuns. Neste cenário, as perdas suportadas, no país contagiante, forçam os bancos credores comuns ao reforço de provisões e à recapitalização, além de diminuírem a sua capacidade creditícia, nos países contagiados, recusando a concessão de novos empréstimos ou o roll over dos antigos. 
na área do euro, onde a moeda única potencia a probabilidade de uma evolução negativa num Estado-Membro poder comprometer o desenvolvimento económico e a estabilidade na área do euro no seu conjunto" [cfr. Comissão Europeia (2012c, p. 11) $]^{43}$.

Recordemos que o art. ${ }^{\circ} 123$. $^{\circ}$ do TFUE proíbe a monetarização dos défices públicos ${ }^{44}$ - cfr. supra 2.1.-, o que impele os estados-membros a procurarem financiamento junto dos mercados de crédito globais, em concorrência com os restantes devedores soberanos e privados. Acresce que o art. ${ }^{\circ} 124 .^{\circ}$ do TFUE também proíbe qualquer forma de acesso privilegiado do «sector público» às instituições financeiras ${ }^{45}$, o

${ }^{43}$ Um texto praticamente idêntico encontra-se na «exposição dos motivos» da Proposta de Regulamento do Parlamento Europeu e do Conselho que altera o Regulamento (UE) n. ${ }^{\circ} 1093 / 2010$ que cria uma Autoridade Europeia de Supervisão (Autoridade Bancária Europeia) no que respeita à sua interaç̧ão com o Regulamento (UE) $n .^{\circ} \ldots /$. . do Conselho que confere ao Banco Central Europeu atribuições específicas no que diz respeito às políticas relativas à supervisão prudencial das instituições de crédito - cfr. Comissão Europeia (2012d, p. 2).

44 Sobre o significado da proibição do financiamento monetário, consagrada no art. ${ }^{\circ} 123 .^{\circ}$ do TFUE, cfr. Machado (2012, pp. 565-568).

$45 \mathrm{O}$ art. $^{\circ} 3 .^{\circ}$ do Regulamento (CE) $n^{\circ} 3603 / 93$ do Conselho, de 13.12.1993, que especifica as definições necessárias à aplicação das proibições enunciadas no artigo $104 .^{\circ}$ e no $n^{\circ} 1$ do artigo $104^{\circ}-B$ do Tratado - os artigos $104 .^{\circ}$ e $104 .^{\circ}-\mathrm{B}$ da numeração pré-Amesterdão correspondem respectivamente aos artigos $101 .^{\circ}$ e $103 .^{\circ}$ da numeração pós-Amesterdão e aos artigos $123 .^{\circ}$ e $125 .^{\circ}$ do TFUE - compreende no «sector público» "as instituições ou organismos da Comunidade, as administrações centrais, as autoridades regionais ou locais, as outras autoridades públicas e os demais organismos ou empresas públicas dos Estados-membros”.

Por sua vez, o art. $^{\circ} 1 .^{\circ}$ do Regulamento (CE) n. $3604 / 93$ do Conselho, de 13.12.1993, que especifica as definições com vista à aplicação da proibição de acesso privilegiado enunciada no artigo $104 .^{\circ}-A$ do Tratado - o art. ${ }^{\circ} 104 .^{\circ}-\mathrm{A}$ da numeração pré-Amesterdão corresponde ao art. ${ }^{\circ} 102 .^{\circ}$ da numeração pós-Amesterdão e ao art. $^{\circ} 124 .^{\circ}$ do TFUE - delimita positiva e negativamente o âmbito de aplicação do conceito de «medidas que possibilitem o acesso privilegiado». 
que reforça a matriz concorrencial do mercado da dívida pública ${ }^{46}$.

Sublinhe-se que a concorrência pelo financiamento não opera apenas entre diferentes estados soberanos, mas também entre mutuários públicos e privados, ou seja, o mercado da dívida pública e o mercado da dívida privada tornaram-se segmentos do mesmo mercado de crédito global, onde prestamistas e devedores disputam as condições dos empréstimos, mormente os montantes, os prazos, as taxas de juro e as garantias.

Destarte, o crowding out $^{47}$ não se verifica apenas no seio de cada estado-membro, nem sequer se circunscreve ao mercado interno europeu, mas sobrevém à escala global de mercados de crédito desregulamentados e de movimentos de capitais liberalizados.

Porém, quando os mercados de crédito internacionais avaliam o risco dos devedores privados tomam em linha de conta o risco dos respectivos países de origem, ou seja, o sovereign rating condiciona o corporate rating. Consequentemente, a notação negativa da dívida soberana de um estado-membro

Mais recentemente, o Regulamento (CE) n. $479 / 2009$ do Conselho, de 25.05.2009, relativo à aplicação do Protocolo sobre o procedimento relativo aos défices excessivos anexo ao Tratado que institui a Comunidade Europeia, alterado pelo Regulamento (UE) n. ${ }^{\circ}$ 679/2010 do Conselho, de 26.07.2010, - o Regulamento (CE) n. ${ }^{\circ} 479 / 2009$ revogou o Regulamento (CE) $n .^{\circ} 3605 / 93$ do Conselho, de 22.11.1993, relativo à aplicação do protocolo sobre o procedimento relativo aos défices excessivos anexo ao Tratado que institui a Comunidade Europeia - adequa as noções do Protocolo sobre o procedimento relativo aos défices excessivos, anexo ao TUE e ao TFUE, à nomenclatura do Sistema Europeu de Contas Nacionais e Regionais na Comunidade, adoptado pelo Regulamento (CE) n. ${ }^{\circ}$ 2223/96 do Conselho, de 25.06.1996.

46 Sobre o sentido da proibição de acesso privilegiado ao financiamento, prevista no art. $^{\circ} 124 .^{\circ}$ do TFUE, cfr. CABO (2012, pp. 569-572).

47 Sobre a noção de crowding out, cfr. Blanchard (2002, pp. 728$-730)$. 
deprecia as notações dos emitentes privados sediados nesse estado.

Neste cenário, as empresas europeias concorrem num mercado único de bens e de serviços, com livre circulação de trabalhadores e de capitais, mas não beneficiam de um mercado único de financiamento.

Ora, o excerto citado da Comissão Europeia (2012c) alerta para a correlação entre a notação da dívida pública e a notação da dívida privada, maxime para a dependência dos ratings bancários em relação aos ratings soberanos dos respectivos estados. Assim, instituições de crédito com resultados positivos nos «stress tests» ${ }^{48}$ podem receber notações de rating negativas e instituições de crédito com resultados negativos nos «stress tests» podem receber notações de rating positivas.

Em suma, a ausência de um mercado bancário único supõe a fragmentação dos mercados de crédito à escala nacional, o que enviesa a comparabilidade entre as notações de rating de bancos dos diferentes estados-membros. Um dos caminhos para a desfragmentação dos mercados bancários passa pela destrinça entre a evolução da dívida soberana e a da dívida bancária, no intuito de quebrar os «ciclos de retroacção negativa», a que alude a Comissão Europeia (2012c, p. 11).

${ }^{48} \mathrm{O}_{\text {art. }}{ }^{\circ} 21 .^{\circ}$, n. $^{\circ}$ 2, al. b), do Regulamento n. ${ }^{\circ}$ 1096/2010, atribui à Autoridade Bancária Europeia, em cooperação com o Comité Europeu de Risco Sistémico, a competência para a realização de «testes de esforço", que avaliem a resiliência das instituições de crédito perante situações adversas.

As metodologias e os procedimentos, bem como os cenários e os resultados dos «testes de esforço», estão disponíveis no site da Autoridade Bancária Europeia: < http://www.eba.europa.eu >. 


\section{A contenção do financiamento público das opera- ções de bailout}

O Roteiro para uma união bancária sustenta que as operações de bailout custaram 4,5 biliões de euros aos contribuintes europeus, entre Outubro de 2008 e Outubro de 2011 - cfr. Comissão Europeia (2012a, p. 2$)^{49}$.

49 A versão inglesa da Comunicação Roadmap towards a Banking Union refere expressamente "€4,5 trillion", o que corresponde aos dados do Relatório Final do High-level Expert Group on reforming the structure of the EU banking sector, apresentado em 2 de Outubro de 2012 - cfr. Lituanen, Bänziger, Campa, Gallois, Goyens, Krahnen, Mazzucchelli, Sergeant, Tuma, Vanhevel e Wijffels (2012), cujo quadro da página 21 aqui se transcreve:

STATE AID MEASURES IN THE CONTEXT OF THE FINANCIAL AND ECONOMIC CRISIS

Between 2008 and October 2011, the national parliaments of the Member States committed in total to $€ 4.5$ trillion ( $36.7 \%$ of EU GDP) of state aid measures, the majority of which in the form of guarantees on bank liabilities with maturities up to 5 years.

Parliamentary approved amounts of state aid in the period $10 / 2008-10 / 2011$ in the $\mathrm{EU}$ :

\begin{tabular}{|c|c|c|l|c|c|c|}
\hline & Guarantees & $\begin{array}{c}\text { Liquidity } \\
\text { measures }\end{array}$ & Recapitalisation & $\begin{array}{c}\text { Impaired } \\
\text { assets }\end{array}$ & \multicolumn{2}{|c|}{ Total } \\
\hline Years & $€$ billion & $€$ billion & $€$ billion & $€$ billion & $€$ billion & $\begin{array}{c}\% \text { of } \\
\text { GDP }\end{array}$ \\
\hline 2008 & 3097 & 85 & 270 & 5 & 3457 & 27.7 \\
\hline 2009 & 88 & 5 & 110 & 339 & 542 & 4.6 \\
\hline 2010 & 55 & 67 & 184 & 78 & 384 & 3.1 \\
\hline 2011 & 49 & 40 & 34 & 0 & 123 & 1 \\
\hline $\mathbf{2 0 0 8 - 2 0 1 1}$ & $\mathbf{3 2 9 0}$ & $\mathbf{1 9 8}$ & $\mathbf{5 9 8}$ & $\mathbf{4 2 1}$ & $\mathbf{4 5 0 6}$ & $\mathbf{3 6 . 7}$ \\
\hline
\end{tabular}

Fonte: Limkanen, Bänziger, Campa, Gallois, Goyens, Krahnen, Mazzucchelli, Sergeant, Tuma, Vanhevel e Wijffels (2012, p. 21, Box 2.2). 
Para se proferir um juízo relativo das ordens de grandeza envolvidas nas operações de resgate, confrontem-se os dados do quadro anterior com os valores do PIB dos 27 Estados-membros, entre 2008 e 2009:

\begin{tabular}{|c|c|c|c|c|}
\hline \multicolumn{5}{|c|}{ GROSS DOMESTIC PRODUCT AT MARKET PRICES } \\
\hline \multicolumn{5}{|c|}{$\begin{array}{r}\text { Unit: Millions of euro } \\
\text { Last update: 22-01-2013 }\end{array}$} \\
\hline GEO/TIME & 2008 & 2009 & 2010 & 2011 \\
\hline EU27 - European Union & $12.473 .093,8$ & $11.754 .435,0$ & $12.279 .914,7$ & 12.642.728,9 \\
\hline $\mathrm{BE}$ - Belgium & $346.375,0$ & $340.777,0$ & $356.125,0$ & $369.836,0$ \\
\hline BG - Bulgaria & $35.430,5$ & $34.932,8$ & $36.052,4$ & $38.483,2$ \\
\hline CZ - Czech Republic & $154.269,7$ & $142.197,0$ & $150.274,8$ & $156.216,8$ \\
\hline DK - Denmark & $235.133,0$ & $223.575,8$ & $236.477,1$ & $240.452,8$ \\
\hline DE - Germany & $2.473 .800,0$ & $2.374 .500,0$ & $2.496 .200,0$ & $2.592 .600,0$ \\
\hline EE - Estonia & $16.235,1$ & $13.761,7$ & $14.322,7$ & $15.951,4$ \\
\hline IE - Ireland & $178.881,6$ & $161.275,1$ & $156.486,7$ & $158.992,7$ \\
\hline EL - Greece & $233.197,7$ & $231.081,2$ & $222.151,5$ & $208.531,7$ \\
\hline ES - Spain & $1.087 .788,0$ & 1.048.060,0 & $1.048 .883,0$ & $1.063 .355,0$ \\
\hline FR - France & $1.933 .195,0$ & $1.885 .763,0$ & $1.937 .261,0$ & $1.996 .583,1$ \\
\hline IT - Italy & $1.575 .143,9$ & $1.519 .695,1$ & $1.553 .083,2$ & $1.579 .659,2$ \\
\hline CY - Cyprus & $17.157,1$ & $16.853,5$ & $17.406,0$ & $17.979,3$ \\
\hline LV - Latvia & $22.889,8$ & $18.521,3$ & $18.038,9$ & $20.211,4$ \\
\hline LT - Lithuania & $32.414,3$ & $26.654,4$ & $27.607,5$ & $30.806,9$ \\
\hline LU - Luxembourg & $37.371,5$ & $36.026,5$ & $39.905,5$ & $42.624,6$ \\
\hline HU - Hungary & $105.535,8$ & $91.415,4$ & $96.585,4$ & $99.818,9$ \\
\hline MT - Malta & $5.964,9$ & $5.972,5$ & $6.314,3$ & $6.544,4$ \\
\hline NL - Netherlands & $594.481,0$ & $573.235,0$ & $588.740,0$ & $601.973,0$ \\
\hline AT - Austria & $282.744,2$ & $276.151,0$ & $286.396,9$ & $300.712,4$ \\
\hline PL - Poland & $363.175,3$ & $310.681,4$ & $354.616,1$ & $369.665,8$ \\
\hline PT - Portugal & $171.983,1$ & $168.503,6$ & $172.834,8$ & $171.039,9$ \\
\hline RO - Romania & $139.765,4$ & $118.196,0$ & $124.327,7$ & $131.327,0$ \\
\hline
\end{tabular}


O «pacote legislativo», de 24 Novembro de 2010, já denunciava o peso dos bailouts para os orçamentos públicos dos estados-membros e propunha, em alternativa, a internalização dos custos dos resgates bancários, através do lançamento de impostos sobre as instituições de crédito $^{50}$. Aliás, o «considerando 37» do Regulamento que cria a Autoridade Bancária Europeia e o «considerando 37» do Regulamento que cria a Autoridade Europeia dos Valores Mobiliários e dos Mercados assumiam

\begin{tabular}{l|r|r|r|r|}
\hline SI - Slovenia & $37.244,4$ & $35.556,1$ & $35.607,0$ & $36.171,8$ \\
\hline SK - Slovakia & $64.413,5$ & $62.794,4$ & $65.869,5$ & $69.108,3$ \\
\hline FI - Finland & $185.670,0$ & $172.318,0$ & $178.796,0$ & $189.368,0$ \\
\hline SE - Sweden & $333.255,7$ & $292.472,1$ & $349.945,1$ & $387.596,0$ \\
\hline UK - United Kingdom & $1.809 .578,3$ & $1.573 .465,1$ & $1.709 .606,7$ & $1.747 .119,4$ \\
\hline \multicolumn{4}{|l|}{$\begin{array}{l}\text { Fonte: EurosTAT, quadro gerado online, no site: < http://appsso.eurostat.ec.europa. } \\
\text { eu/nui/show.do >, correspondente ao indicador GDP and main components - Current prices, } \\
\text { extraído em 27.01.2013. }\end{array}$}
\end{tabular}

Em 2008, as medidas de auxílio aprovadas pelos parlamentos nacionais dos 27 estados-membros ascenderam a 3457 biliões de euros, o que representa $27,7 \%$ dos 12473 biliões de euros do total do PIB da União Europeia. Grosso modo, as medidas de auxílio aprovadas, nesse ano, equivaleram a 1,4 vezes do PIB alemão, a 1,8 vezes do PIB francês, a 1,9 vezes do PIB britânico, a 2,2 vezes do PIB italiano, a 3,2 vezes do PIB espanhol e a 20 vezes do PIB português.

Entre 2008 e 2011, o montante do auxílio total remontou a 4506 biliões de euros, o que representa 9,2\% do somatório do PIB dos 27 estados-membros do mesmo período. Sublinhe-se que - no total dos 4 anos - os 4506 biliões de euros equivalem, respectivamente, a 45,3\% do somatório do PIB alemão, a $58,1 \%$ do somatório do PIB francês, a $65,9 \%$ do somatório do PIB britânico, a 72,4\% do somatório do PIB italiano, a $106,1 \%$ do somatório PIB espanhol e a $658,4 \%$ do somatório do PIB português.

${ }^{50}$ Sobre o alcance das propostas de internalização de custos, apresentadas no "pacote legislativo" de Novembro de 2010, cfr. QuelHas (2012a, pp. 887-891). 
inequivocamente o objectivo da internalização dos custos das operações de bailout.

Neste sentido, o art. $.^{\circ} 27 .^{\circ}$ do Regulamento n. ${ }^{\circ}$ 1093/2010 estabeleceu um «Sistema europeu de dispositivos de resolução bancária e mecanismos de financiamento», que seria sustentado pela criação de "taxas e contribuições a cargo das institui-

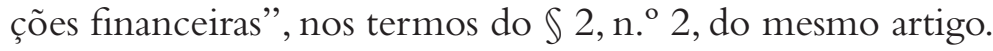

Do mesmo modo, o art. ${ }^{\circ} 27 .^{\circ}$, n. $^{\circ} 2, \$ 2$, do Regulamento n. ${ }^{\circ}$ 1095/2010 também previu que a instituição do «Sistema europeu de dispositivos de resolução bancária e mecanismos de financiamento" fosse suportada pela criação de "taxas e contribuições a cargo das instituições financeiras".

A internalização dos custos, através da cobrança de "taxas e contribuições” às instituições financeiras, já estava prevista na Comunicação da Comissão, de 7 de Outubro de 2010, intitulada $A$ tributação do sector financeir $0^{51}$, bem como no Documento de Trabalho da Comissão, da mesma data, denominado Financial Sector Taxation ${ }^{52}$.

A Comunicação da Comissão reflecte sobre o papel da fiscalidade para a estabilização do sistema financeiro e examina o impacto da proposta de aplicação de dois novos impostos, a saber: o «imposto sobre as operações financeiras» (IOF) ${ }^{53}$; o «imposto sobre as actividades financeiras» $(\mathrm{IAF})^{54}$.

51 Cfr. Comissão Europeia (2010b).

52 Cfr. Comissão Europeia (2010a).

53 De acordo com a Comissão Europeia (2010b), o IOF incidiria sobre o valor das transacções de vários instrumentos financeiros, nomeadamente, acções, obrigações, divisas e produtos derivados. Porém, a própria Comunicação da Comissão, de 7 de Outubro de 2010, adverte para as dificuldades de execução desta medida, nomeadamente: o âmbito de incidência territorial do imposto; o peso do trading no total das transacções financeiras; a mutabilidade da base tributária por causa da reengenharia financeira; a imaterialidade e a volatilidade dos "produtos financeiros», maxime dos derivados financeiros. 
Segundo as contas da Comissão Europeia (2010b), a aplicação de uma taxa de $0,1 \%$ sobre o volume das operações financeiras com acções e obrigações teria gerado, em 2006, uma receita de IOF de sessenta mil milhões de euros, que decuplicaria, caso o imposto também incidisse sobre derivados. Mas, mesmo que os cálculos se restringissem aos mercados regulamentados de valores mobiliários, a cobrança de IOF sobre as transacções em acções e obrigações ascenderia a vinte mil milhões de euros e, caso se incluíssem os "produtos derivados», a quantia poderia totalizar cento e cinquenta mil milhões de euros.

O principal argumento, esgrimido pela Comissão Europeia (2010b, p. 6), em defesa do IOF sustenta: “... este imposto poderia implementar o princípio do poluidor-pagador, pelo que ajudaria a internalizar potenciais externalidades negativas da actividade financeira. Tem vindo a defender-se que uma ampla base de incidência do IOF poderia ajudar a estabilizar os mercados financeiros, reduzindo as operações especulativas de curto prazo através da penalização das operações indesejáveis, essencialmente o trading de alta frequência”.

Contudo, a Comunicação da Comissão, de 7 de Outubro de 2010, alerta para várias dificuldades técnico-fiscais, mormente: "Em primeiro lugar, os ganhos de eficiência são incertos, já que o imposto pode tornar os preços mais voláteis porque reduz a liquidez, designadamente em mercados que são utilizados para cobrir riscos. Em segundo lugar, ainda que o valor para a economia do trading de alta velocidade seja questionável, a medida em que esta actividade constituiu o principal motor das externalidades negativas na crise ainda está por estudar. Em terceiro lugar, o IOF tributa valores brutos. Uma vez que o IOF incide sobre operações e não sobre valor acrescentado, é cumulativo. Os produtos transaccionados com maior frequência terão uma carga fiscal superior" [cfr. Comissão EuroPEIA (2010b, p. 6)].

De sublinhar, sobretudo, as preocupações reveladas com a redução da liquidez e com a diminuição das operações de cobertura de risco; com efeito, a redução da liquidez pode aumentar a taxa de juro corrente do mercado e a diminuição das operações de cobertura de risco pode aumentar a volatilidade dos preços dos activos subjacentes. Se estas preocupações se revelassem fidedignas, o IOF agravaria a instabilidade, em vez de a atenuar.

Neste sentido, compreende-se a natureza titubeante das conclusões da Comunicação da Comissão Europeia sobre o IOF: "Para ser completamente eficaz, o IOF deveria incidir sobre operações «nocivas» ou 
altamente especulativas. Na prática, não é possível distinguir estas das operações «normais». Em consequência, o IOF teria de incidir sobre a mais ampla base possível para atingir o seu objectivo de eficiência. Um IOF com uma base mais restrita poderia reduzir o risco de relocalização geográfica, desde que fosse concebido correctamente. Mas se só forem tributadas certas operações, o imposto irá distorcer a intermediação financeira, por favorecer certas actividades que não seriam passíveis de IOF. Por outro lado, consoante a sua configuração, o IOF poderia criar oportunidades de evasão devido a reengenharia ou substituição. Para reduzir eficazmente as actividades com externalidades potencialmente negativas a nível global e evitar a relocalização do trading, o imposto deveria aplicar-se em todas as praças financeiras. Estas praças estão fortemente interligadas e as empresas não têm grandes custos quando transferem as operações entre elas. Acresce que muitas sociedades financeiras operam com subsidiárias à escala mundial. Em consequência, o facto de o IOF necessitar de uma base ampla para cumprir os seus objectivos de eficiência e receitas implica também que necessitará de forte coordenação à escala global para reduzir o risco de reafectação ou evasão" [Comissão Europeia (2010b, p. 6)].

A aludida titubeação transparece na própria dicotomia textual, nomeadamente: a indiferenciação prática entre as «operações nocivas» e as «operações normais»; o dilema entre o alargamento da base tributária, para aumentar a eficiência da cobrança, e a redução da base tributária, para diminuir a relocalização geográfica das operações; o agravamento fiscal, para esfriar a especulação e a proliferação de novos «produtos financeiros», versus o desagravamento fiscal, para frear a evasão e desincentivar a reengenharia de substituição de "produtos financeiros» tributados por não tributados.

54 De acordo com a Comunicação da Comissão, de 7 de Outubro de 2010, o IAF incide sobre os lucros das instituições financeiras. Enquanto o IOF configura um imposto indirecto sobre as transacções, o IAF representa um imposto directo sobre os lucros.

Segundo os cálculos da Comissão Europeia (2010b), a aplicação de uma taxa de 5\% sobre os lucros das instituições financeiras, dos 27 estados-membros, geraria uma receita aproximada de 25 mil milhões de euros, a título de IAF.

A Comissão Europeia (2010b) avalia a proposta de criação do IAF à luz de critérios da eficiência e da estabilidade financeira. O IAF passaria o teste da eficiência porque “... tributa a totalidade dos ganhos da 
A Comunicação da Comissão, de 7 de Outubro de 2010, advoga a capacidade estabilizadora sistémica da tributação das instituições financeiras, com base em três argumentos: correcção das externalidades negativas; consolidação orçamental; combate à arbitragem fiscal.

Acerca do primeiro argumento, a Comunicação da Comissão sustenta:

“... a introdução de novos impostos poderia contribuir para o reforço da eficiência e da estabilidade dos mercados financeiros e para reduzir a sua volatilidade, bem como os efeitos nocivos de uma excessiva tomada de riscos. O sector financeiro, em particular, talvez tome demasiados riscos em razão de vários factores que vão desde apoio estatais efectivos ou esperados (que resultam em risco moral) e informações assimétricas a estruturas de remuneração que, associadas à evolução macroeconómica, contribuíram para a recente crise. Assim, o comportamento do sector financeiro cria externalidades negativas para o resto da economia. Justifica-se, por isso, a introdução de um mecanismo fiscal para corrigir tais externalidades, desde que o mesmo possa ser desenhado para cumprir este objectivo" [cfr. Comissão Europeia (2010b, p. 3)].

actividade das instituições financeiras. Neste sentido, incide sobre todas as actividades, não só o trading. Não altera os preços dos instrumentos financeiros, deixando a estrutura do mercado inalterada" [cfr. ComIssão Europeia (2010b, p. 8)]. Porém, o IAF revela fragilidades no combate à instabilidade financeira porque "... não afecta directamente a existência do trading de alta velocidade" e porque "...poderia vir acrescentar-se aos incentivos existentes à transferência de lucros por via da relocalização de rendimentos e de remunerações para fora da UE" [cfr. Comissão EuroPEIA (2010b, p. 8)].

Em suma, apesar de tributar a totalidade dos lucros das instituições financeiras, o IAF geraria receitas inferiores ao IOF porque tem uma base de incidência substancialmente menor. Acresce que a taxa proposta de 5\% sobre os lucros do IAF é superior à taxa de $0,1 \%$ do IOF, ou seja, com a aplicação do IAF perder-se-ia o efeito anestesiante de uma taxa baixa e aumentaria o estímulo para a evasão e para a deslocalização. 
Nestes termos, as externalidades negativas, resultantes de operações e de actividades financeiras, seriam internalizadas pelo sector financeiro, através da tributação dessas operações e actividades, ou seja, os agentes desestabilizadores suportariam os custos da instabilidade que causassem.

Em rigor, a internalização só seria total se os custos da instabilidade fossem delimitáveis e imputáveis aos respectivos autores. Porém, o «efeito de contágio» evidencia que a instabilidade se propaga pelo sistema financeiro, derrubando sucessiva e aceleradamente os vários elos das cadeias de crédito, que extravasam as relações bilaterais entre mutuantes e mutuários.

Destarte, a tributação não incidiria apenas sobre os autores imediatos ou mediatos da desestabilização, mas recairia antes sobre todos os intervenientes em determinadas actividades financeiras. Consequentemente, o objectivo primordial da tributação não seria o do ressarcimento das consequências sistémicas da instabilidade, mas sim o da prevenção de comportamentos desestabilizadores.

Assim, o lançamento de impostos sobre determinadas operações financeiras cumpriria dois objectivos: ex ante, o da profilaxia de comportamentos desestabilizadores contagiosos; ex post, o da arrecadação de receitas para o financiamento de operações de resgate.

Sobre o segundo argumento, a Comunicação da Comissão assevera:

“... o sector financeiro é tido por grande responsável pela ocorrência e a envergadura da crise e os seus efeitos negativos nos níveis de endividamento público à escala mundial. A introdução de novos impostos poderia também justificar-se pelo facto de alguns governos terem dado um apoio substancial ao sector financeiro durante a crise, esperando-se agora uma contrapartida da sua parte. Ao contribuir para a consolidação orçamental e para a geração de recursos adicionais, bem como para a eficiência económica, novos impostos no sector financeiro poderiam criar condições para 
um crescimento mais sustentável, conforme preconiza a estratégia Europa 2020" [cfr. Comissão Europeia (2010b, pp. 3-4)].

Os dados, já examinados, do Relatório Final do High-level Expert Group on reforming the structure of the EU banking sector revelam o impacto dos resgates das instituições de crédito sobre as finanças públicas dos estados-membros.

Num cenário de crise financeira, as idiossincrasias da arquitectura orçamental europeia reemergiram; por um lado, os parlamentos dos estados-membros aprovaram medidas de auxílio aos bancos nacionais, aumentando a despesa pública e, tendencialmente, os défices orçamentais e os níveis de endividamento; por outro, o art. ${ }^{\circ} 126 .^{\circ}$ do TFUE, o Protocolo sobre o procedimento relativo aos défices excessivos e o Pacto de Estabilidade e Crescimento impõem restrições aos défices orçamentais e às rationes de dívida pública desses mesmos estados-membros.

De forma a evitarem "défices excessivos», os estados-membros vêem-se obrigados a compensar o aumento da despesa em bailouts com a subida das receitas fiscais ou com a diminuição das restantes despesas públicas, através da adopção de medidas de austeridade. Acresce que o «critério da dívida pública» restringe a capacidade de financiamento dos resgates bancários, através da contracção de empréstimos públicos. Em suma, a conjugação entre a resposta à crise financeira e o cumprimento dos critérios de Maastricht coloca os estados-membros perante um dilema: ou optam pela estabilidade do sistema financeiro e adoptam medidas de austeridade económica e social ou convivem com a instabilidade do sistema financeiro e rejeitam as medidas de austeridade económica e social.

Em relação ao terceiro argumento, a Comunicação da Comissão observa:

"É importante que estes processos [instituição de mecanismos fiscais] ocorram de uma forma coordenada, caso contrário, as diferenças entre os sistemas nacionais assentes em bases de imposto 
distintas poderiam criar incentivos à arbitragem fiscal e traduzir-se em distorções na repartição entre os mercados financeiros da UE. O emergir de soluções nacionais não coordenadas poderia conduzir também a situações de dupla tributação e à fragmentação do mercado financeiro, o que seria prejudicial ao funcionamento do mercado único" [cfr. Comissão Europeia (2010b, p. 4)].

Este excerto alerta para a diversidade dos sistemas fiscais ainda preponderante na União Europeia. Com efeito, apesar das medidas de coordenação fiscal já adoptadas, o mercado único caracteriza-se pela incipiência da harmonização fiscal entre os estados-membros. Esta fragilidade é particularmente sensível nos mercados financeiros, por causa da liberalização dos movimentos de capitais entre os estados-membros e entre os estados-membros e países terceiros, a partir da 1. ${ }^{a}$ fase da UEM, e, sobretudo, da partilha da mesma moeda pelos países participantes na $3 .^{\text {a }}$ fase da UEM.

Deste modo, a instituição de políticas monetárias e cambiais únicas não foi acompanhada pelo estabelecimento de políticas fiscais únicas, o que revela um desfasamento entre os ritmos de evolução da política monetária e da política fiscal ${ }^{55}$. Só que esta descoordenação propicia situações de arbitra-

55 Este desfasamento está consagrado no próprio TFUE. Basta confrontar as disposições relativas à política monetária com as normas referentes à política fiscal. Assim, o art. ${ }^{\circ} 119 .^{\circ}$, n. ${ }^{\circ}$ 2, do TFUE, estatui que “... nos termos e segundo os procedimentos previstos nos Tratados, essa acção [alcançar os fins enunciados no art. $^{\circ} 3 .^{\circ}$ do TUE] implica uma moeda única, o euro, e a definição e condução de uma política monetária e de uma política cambial únicas, cujo objectivo primordial é a manutenção da estabilidade dos preços e, sem prejuízo desse objectivo, o apoio às políticas económicas gerais na União, de acordo com o princípio de uma economia de mercado aberto e de livre concorrência”. Aliás, logo o art. $^{\circ} 3 .^{\circ}$, n. $^{\circ} 4$, do TUE consagra que "A União estabelece uma união económica e monetária cuja moeda é o euro". Por seu turno, as normas concernentes à política fiscal são remetidas para o seio das "regras comuns relativas à concorrência, à fiscalidade e à aproximação das legislações" e a sua adopção sujeita ao princípio da unanimidade - cfr. artigos $110 .^{\circ}$ a $114 .{ }^{\circ}$ do TFUE. 
gem fiscal e, em última instância, a fragmentação do mercado financeiro europeu.

Na senda da Comunicação, de 7 de Outubro de 2010, a Comissão Europeia apresentou, em 28 de Setembro de 2011, uma Proposta de Directiva do Conselho sobre um sistema comum de imposto sobre as transacções financeiras e que altera a Directiva 2008/7/CE ${ }^{56}$, que enquadrou nos seguintes termos:

"A recente crise económico-financeira mundial teve um impacto grave nas nossas economias e nas finanças públicas. $\mathrm{O}$ sector financeiro desempenhou um papel fundamental no desencadeamento da crise, enquanto os governos e os cidadãos europeus na retaguarda arcaram com os custos. Tanto na Europa, como a nível internacional, existe uma forte impressão de que o sector financeiro deveria contribuir de modo mais equitativo, dados os custos de gestão da crise e a actual subtributação do sector.Vários Estados-Membros da UE já tomaram medidas divergentes no domínio da tributação do sector financeiro. A presente proposta visa uma abordagem europeia comum a esta questão que seja coerente com o mercado interno; pretende complementar o quadro normativo da UE, que tem por objectivo tornar os serviços financeiros mais seguros, através da correcção dos comportamentos particularmente arriscados em alguns segmentos dos mercados financeiros, de maneira a evitar a repetição de práticas do passado" [Cfr. Comissão Europeia (2011c, p. 2)].

Nas palavras de Palma (2012, p. 531), “A harmonização fiscal nunca foi um fim em si mesmo, mas apenas um meio de atingir os objectivos fundamentais dos Tratados, não existindo uma política fiscal comum", o que evidencia a natureza instrumental da política fiscal, no ordenamento jurídico-económico da União Europeia. No mesmo sentido, CunHA (2012, p. 538) acrescenta: "Não obstante os laboriosos esforços de harmonização fiscal realizados, persiste ainda uma forte fragmentação fiscal, sendo a unanimidade apontada como principal obstáculo. Por outro lado, a introdução da moeda única acentuou a necessidade de convergência das políticas fiscais dos EM. Acresce que o mercado interno se encontra inacabado e cumpre envidar esforços no sentido de aprofundar a sua realização, bem como de melhorar o seu funcionamento".

${ }^{56}$ Cfr. Comissão Europeia (2011c). 
De sublinhar que a Proposta enseja a obtenção de dois objectivos: a sustentabilidade das finanças públicas dos estados-membros, através do aumento das receitas fiscais; a estabilização do sistema financeiro europeu, através da internalização dos custos pelos operadores. Acresce que os dois objectivos são convergentes porque o crescimento das receitas fiscais seria suportado pelos impostos cobrados aos agentes causadores da instabilidade.

Destarte, as externalidades negativas sistémicas seriam financiadas pelos impostos cobrados aos desestabilizadores/ /pagadores e não pelos tributos suportados pela generalidade dos contribuintes. Esta forma de internalização dos custos seria relevante para o reequilíbrio das finanças públicas, sucessivamente desfalcadas pelo aumento das despesas com bailouts, e contribuiria também para o reforço da coesão social.

Com efeito, os resgates bancários aumentaram as despesas públicas e agravaram os défices orçamentais, em vários estados-membros, o que desencadeou o aumento generalizado da carga fiscal e a adopção de políticas de austeridade. Neste contexto, a aplicação do princípio do desestabilizador/pagador imputaria os custos da instabilidade aos seus causadores, diminuindo a injustiça redistributiva, resultante do financiamento público dos bailouts, ao mesmo tempo que a arrecadação de novas receitas permitiria o alívio da pressão fiscal sobre os outros contribuintes e a atenuação das medidas de austeridade.

Sublinhe-se que a Proposta de Directiva do Conselho, de 28 de Setembro de 2011, elege três objectivos, enunciados nos desígnios de contribuir:

“- Para evitar a fragmentação do mercado interno dos serviços financeiros, tendo em conta o número crescente de medidas fiscais nacionais descoordenadas que existe;

- Para assegurar que as instituições financeiras contribuam de maneira justa para os custos da recente crise e para assegurar uma equidade do ponto de vista fiscal com os outros sectores; 
- Para criar medidas apropriadas para desincentivar transacções que não aumentem a eficiência dos mercados financeiros, complementando, assim, medidas reguladoras que visam impedir crises futuras" [cfr. Comissão Europeia (2011c, p. 2)].

Além dos objectivos de equidade contributiva, na repartição dos custos dos bailouts, e de internalização de externalidades negativas sistémicas, a Proposta de Directiva adverte para a hipótese de fragmentação dos mercados financeiros, na União Europeia, e enfatiza a importância da coordenação, entre os estados-membros, em matéria de regulação e de supervisão, com vista à salvaguarda da estabilidade do sistema financeiro.

A coordenação entre os estados-membros surge como o elemento nodal da Proposta de Directiva, não apenas com o propósito imediato de travar a fragmentação dos mercados financeiros, mas também com o desígnio de garantir a estabilidade do mercado interno. Aliás, a «financeirização» crescente da actividade económica faz com que a estabilidade dos mercados reais seja indissociável da estabilidade dos mercados financeiros. Neste sentido, a instituição de um sistema comum de imposto sobre as transacções financeiras prossegue o objectivo primordial de preservar o próprio mercado interno.

Em abono da verdade, a Proposta de Directiva do Conselho, de 28 de Setembro de 2011, extravasa a matéria da fiscalidade das transacções financeiras e insere-se na reforma do sistema de financiamento da União Europeia. Com efeito, a Proposta de Decisão do Conselho relativa ao sistema de recursos próprios da União Europeia, de 29 de Junho de $2011^{57}$, e a Proposta alterada de Decisão do Conselho relativa ao sistema de recursos próprios da União Europeia, de 9 de Novembro de 201158, bem como a Proposta de Regulamento do Conselho relativo aos métodos e ao procedimento para a colocação à disposição do recurso próprio baseado

\footnotetext{
57 Cfr. Comissão Europeia (2011b).

58 Cfr. Comissão Europeia (2011a).
} 
no imposto sobre as transaç̧ões financeiras, de 9 de Novembro de $2011^{59}$, alteram a forma de financiamento do orçamento da União Europeia.

Um dos aspectos mais relevantes da reforma do sistema de financiamento é o da introdução do «imposto sobre operações financeiras» (IOF), justificada nos seguintes termos:

"O imposto sobre operações financeiras (IOF) poderá proporcionar um novo fluxo de receitas, o que permitirá reduzir as actuais contribuições dos Estados-Membros, conceder aos Governos nacionais uma maior margem de manobra e contribuir para o esforço geral de consolidação orçamental. Embora já existam algumas formas de tributação das operações financeiras num número limitado de Estados-Membros, a análise realizada permitiu concluir que uma acção a nível da UE se pode revelar mais eficaz e eficiente do que uma acção não coordenada a nível dos Estados-Membros, tendo em conta o nível da actividade transfronteiriça e a elevada mobilidade das matérias colectáveis. Além disso, este impacto poderá desempenhar um papel na redução da actual fragmentação do mercado interno" [cfr. Comiss̃̃o Europeia (2011b, p. 5)].

Além dos objectivos anteriormente apontados para o IOF, a Proposta relativa ao sistema de recursos próprios insere a nova figura nos processos de reforma das finanças públicas da União Europeia e de consolidação orçamental dos estados-membros. Com efeito, o IOF aumentaria as receitas próprias à disposição do orçamento geral da União Europeia, o que reduziria as contribuições dos estados-membros. Consequentemente, os montantes que estes deixariam de transferir para o orçamento comunitário poderiam ser destinados à redução dos défices orçamentais nacionais e à amortização da dívida pública.

Em rigor, a caracterização completa do «sistema comum de imposto sobre as transacções financeiras» (ITF) só é com-

59 Cfr. Comissão Europeia (2011d). 
preensível pela conjugação da Proposta de Decisão do Conselho, de 29 de Junho de 2011, da Proposta de Directiva do Conselho, de 28 de Setembro de 2011, da Proposta alterada de Decisão do Conselho, de 9 de Novembro de 2011, e da Proposta de Regulamento do Conselho, de 9 de Novembro de 2011.

Sublinhe-se que o ITF configura, no essencial, o projecto do IOF, apresentado na Comunicação da Comissão, de 7 de Outubro de 2010, redefinindo as normas de incidência, de determinação da matéria colectável, de lançamento e de cobrança, e reajustando as taxas inicialmente propostas.

O ITF pretende tributar a generalidade das transacções financeiras, praticadas pela maioria das instituições ${ }^{60}$, sujei-

${ }^{60} \mathrm{O}$ art. $^{\circ} 1 .^{\circ}$, n. $^{\circ}$ 2, da Proposta de Directiva sobre um sistema comum de imposto sobre as transacções financeiras estabelece o objecto e âmbito de aplicação do ITF, nos seguintes termos: "A presente directiva é aplicável a todas as operações financeiras, na condição de que, pelo menos, uma parte na transacção seja estabelecida num Estado-Membro e que uma instituição financeira estabelecida no território de um Estado-Membro seja parte na transacção, quer agindo por sua própria conta, ou por conta de outrem, ou em nome de outra parte na transacção".

Apesar de o n. ${ }^{\circ} 3$ e o n. ${ }^{\circ} 4$ do art. $^{\circ} 1$ excepcionarem algumas entidades e várias transacções, a Proposta de Directiva tem uma vocação totalizante, que é evidenciada pelas enumerações sucessivas do $\operatorname{art}^{\circ}{ }^{\circ} 2 .^{\circ}$, nomeadamente operações sobre acções, obrigações, «instrumentos do mercado monetário», fundos de investimento, "produtos estruturados», derivados, «acordos de recompra» e «empréstimos de valores mobiliários». Sublinhe-se que a própria «explicação pormenorizada da proposta» salienta: "A definição de instituição financeira é vasta e inclui, essencialmente, as empresas de investimento, os mercados organizados, as instituições de crédito, as empresas de seguros e de resseguros, os organismos de investimento colectivo e respectivas sociedades de gestão, os fundos de pensões e respectivos gestores, as sociedades gestoras de participações sociais, as empresas de locação financeira, as entidades de finalidade especial e, sempre que possível, remete para as definições consagradas na legislação pertinente da UE, adoptada para fins de regulação. Além disso, outras pessoas que exercem determinadas actividades financeiras numa base significativa devem ser consideradas instituições financeiras" [cfr. Comissão Europeia (2011c, p. 8)]. 
tando-as a duas taxas mínimas: $0,1 \%$ sobre as operações que não envolvam derivados; $0,01 \%$ sobre as operações que envolvam derivados.

\section{O progresso da coordenação supervisora para a harmonização decisória}

O «pacote legislativo» de Novembro de 2010 alertou para a importância da coordenação entre as autoridades supervisoras europeias e propôs a instituição de mecanismos de decisão comuns.

O Regulamento n. ${ }^{\text {o } 1092 / 2010 ~ i n s t i t u i u ~ o ~ S i s t e m a ~ E u r o-~}$ peu de Supervisão Financeira (SESF), composto, nos termos do $\operatorname{art.}^{\circ}$ 1. $^{\circ}$, n. $^{\circ} 3$, pelo Comité Europeu do Risco Sistémico, pela Autoridade Bancária Europeia, pela Autoridade Europeia dos Seguros e Pensões Complementares de Reforma, pela Autoridade Europeia dos Valores Mobiliários e dos Mercados, pelo Comité Conjunto das Autoridades Europeias de Supervisão e pelas autoridades competentes ou de supervisão dos Estados-Membros.

O art. ${ }^{\circ}$ 3. $^{\circ}$, n. ${ }^{\circ}$ 2, al. g), do Regulamento n. ${ }^{\circ}$ 1092/2010, atribui ao Comité Europeu de Risco Sistémico competências para "Cooperar estreitamente com todas as outras partes no SESF; se for caso disso, facultar às ESAs as informações sobre riscos sistémicos necessárias para o exercício das respectivas atribuições e, em particular, definir, em colaboração com as ESAs, um conjunto comum de indicadores quantitativos e qualitativos (painel de riscos) para a identificação e medição do risco sistémico". Destarte, a gestão do risco sistémico exige

De notar que a emissão de acções e de obrigações, no mercado primário, estariam isentas de ITF, para estimular o investimento produtivo e privilegiar o financiamento não especulativo. 
a actuação coordenada das várias autoridades de supervisão, bem como a partilha de informações e a definição de "painéis de risco», susceptíveis de serem monitorizados e avaliados ${ }^{61}$.

Por sua vez, a al. i), do mesmo artigo, acrescenta que ao Comité Europeu de Risco Sistémico compete "Coordenar as suas acções com as das organizações financeiras internacionais, em particular o FMI e o Conselho de Estabilidade Financeira, e com os organismos interessados de países terceiros, no que respeita a questões relacionadas com a supervisão macroprudencial". Deste modo, a cooperação interinstitucional deveria abarcar, inter alia, o FMI, o Conselho de Estabilidade Financeira, o Banco de Pagamentos Internacionais e os G-20, ou seja, a natureza sistémica das crises exige uma resposta concertada à escala internacional, por força da integração crescente dos mercados e dos operadores financeiros.

De forma elucidativa, os três Regulamentos que criam a Autoridade Bancária Europeia, a Autoridade Europeia dos Seguros e Pensões Complementares de Reforma e a Autoridade Europeia dos Valores Mobiliários e dos Mercados partilham o texto do "considerando 1», segundo o qual:

“A crise financeira de 2007 e 2008 veio tornar patentes importantes deficiências na supervisão financeira, tanto em casos específicos como em relação ao sistema financeiro no seu conjunto. Os modelos de supervisão numa base nacional não acompanharam a globalização financeira e a realidade de integração e interligação entre os mercados financeiros europeus, nos quais muitas instituições financeiras desenvolvem as suas operações além-fronteiras. A crise veio expor sérias deficiências nas áreas da cooperação, da coordenação e da coerência de aplicação da legislação da União, bem como a nível da confiança entre as autoridades nacionais de supervisão" [cfr. «considerando 1» dos Regulamentos n. ${ }^{\circ}$ 1093/2010, n. ${ }^{\circ}$ 1094/2010 e n. $\left.{ }^{\circ} 1095 / 2010\right]$.

61 Sobre o significado e o alcance da criação de "painéis de risco", cfr. QuelHas (2012a, p. 883). 
Deste modo, os três regulamentos fundadores das autoridades europeias de supervisão são unânimes sobre o diagnóstico da situação vigente em 2010: os modelos nacionais de supervisão não respondem aos problemas inerentes à globalização e à integração dos mercados, à escala europeia e internacional; a resposta exige a cooperação, a coordenação e a coerência entre as autoridades nacionais de supervisão, compreendidas num quadro regulamentar e institucional europeu comum.

As mesmas insuficiências são reafirmadas, no seguinte texto, repetido nos «considerandos» dos três regulamentos fundadores das autoridades europeias de supervisão:

"A União atingiu os limites do que pode ser feito no quadro do actual estatuto dos comités europeus de autoridades de supervisão. A União não pode continuar numa situação em que não existe qualquer mecanismo para assegurar que as autoridades nacionais de supervisão adoptem as melhores decisões no que respeita à supervisão das instituições financeiras transfronteiriças; em que a cooperação e o intercâmbio de informações entre autoridades nacionais de supervisão são insuficientes; em que qualquer acção conjunta por parte dessas autoridades exige mecanismos complicados para tomar em consideração a disparidade dos requisitos regulamentares e de supervisão; em que as soluções a nível nacional constituem na maior parte das vezes a única opção praticável para dar resposta aos problemas da União; e em que existem diferentes interpretações dos mesmos textos legais. O Sistema Europeu de Supervisão Financeira [...] deverá ser estruturado de modo a ultrapassar essas deficiências e proporcionar um sistema que seja conforme com o objectivo de garantir um mercado de serviços financeiros estável e único para toda a União, que associe as autoridades nacionais de supervisão numa rede reforçada da União" [cfr. o "considerando 8" do Regulamento n. ${ }^{\circ}$ 1093/2010 e o "considerando 7» do Regulamento n. ${ }^{\circ} 1094 / 2010$, bem como o "considerando 8» do Regulamento n. ${ }^{\circ} 1095 / 2010$, que reproduz, quase na integra, o mesmo texto].

Nestes termos, a fundamentação para a reforma do quadro institucional e regulamentar de supervisão da União 
Europeia reafirma a insuficiência das soluções vigentes, em Novembro de 2010, mormente as resultantes do funcionamento dos "colégios de autoridades de supervisão» ${ }^{62}$, previstos na Directiva 2006/48/CE.

Sublinhe-se que o excerto citado faz uma leitura acutilante do grau de coordenação vigente entre as autoridades de supervisão dos estados-membros, denunciando várias insu-

62 Os «colégios de autoridades de supervisão» revelaram-se instrumentos de coordenação insuficiente perante a deflagração de crises financeiras sistémicas.

Mesmo após a entrada em vigor da Directiva 2009/111/CE do Parlamento e do Conselho, de 16 de Setembro de 2009, que altera as Directivas 2006/48/CE, 2006/49/CE e 2007/64/CE no que diz respeito aos bancos em relação de grupo com instituições centrais, a determinados elementos relativos aos fundos próprios, a grandes riscos, a disposições relativas à supervisão e à gestão de crises, o objecto dos "colégios de autoridades» continua a privilegiar a supervisão prudencial de grupos bancários, numa base consolidada, quando as sociedades-mãe e as suas filiais e sucursais operem em jurisdições diferentes.

A fundamentação da Directiva 2009/111/CE refere expressamente - cfr. o "considerando 8》 - os objectivos de "evitar incoerências e a arbitragem regulamentar", bem como de obstar ao "uso de poderes discricionários por parte dos Estados-Membros”. Neste sentido, a Directiva 2009/111/CE estatui proficuamente sobre as relações entre as autoridades de supervisão do estado-membro de origem e de destino, mormente quando insere o artigo art. $^{\circ} 131 .^{\circ}-\mathrm{A}$ na redacção da Directiva 2006/48/CE.

O teor do art. ${ }^{\circ} 131 .^{\circ}-A$, já alterado pela Directiva 2010/78/UE do Parlamento Europeu e do Conselho, de 24.11.2010, e pela Directiva 2011/89/UE do Parlamento Europeu e do Conselho, de 16.11.2011, estabelece regras concernentes à supervisão, em base consolidada, de grupos bancários, nomeadamente sobre a repartição de responsabilidades, os requisitos prudenciais, as normas técnicas de execução, o intercâmbio de informações e a avaliação do risco do grupo.

Embora prossigam o objectivo global de preservação da estabilidade sistémica, a actividade dos «colégios de autoridades» privilegia a supervisão, numa base consolidada, dos grupos bancários. Acresce que a estabilidade dos grupos transfronteiriços contribui para a estabilidade do sistema financeiro, mas esta não se circunscreve àquela. 
ficiências, mormente no que concerne ao controlo das instituições transfronteiriças, ao intercâmbio de informações, à diversidade de regras de supervisão e à dispersão legislativa dos estados-membros.

Para a superação destas insuficiências, um dos passos marcantes - introduzido pelo "pacote legislativo» de Novembro de 2010 e reafirmado nas Propostas de Setembro de 2012 foi a criação do Comité Conjunto das Autoridades Europeias de Supervisão, prevista, respectivamente, nos capítulos dedicados aos "Organismos conjuntos das Autoridades Europeias de Supervisão» dos Regulamentos n. ${ }^{\circ}$ 1093/2010, n. ${ }^{\circ} 1094 / 2010$ e n. ${ }^{\circ} 1095 / 2010$.

$\mathrm{O}$ art. $^{\circ} 54 .^{\circ}$ - numeração e teor comuns aos três regulamentos - estabelece, para o Comité Conjunto, os objectivos da cooperação interinstitucional e da coerência intersectorial, sublinhado algumas das áreas de supervisão mais sensíveis, nomeadamente: as formas de controlo dos conglomerados financeiros; as regras de contabilidade e de auditoria; as análises de risco; o branqueamento de capitais; o intercâmbio de informações.

$\mathrm{O}$ art. ${ }^{\circ} 55 .^{\circ}$ - também com numeração e teor comuns aos três regulamentos - estabelece que o Comité Conjunto é composto pelos presidentes das três autoridades europeias de supervisão, bem como pelos presidentes dos subcomités que venham a ser criados. A presidência é assegurada rotativamente pelos presidentes das autoridades europeias de supervisão, em mandatos anuais.

Os objectivos de cooperação interinstitucional e da coerência intersectorial estão patentes na própria estrutura orgânica das várias autoridades europeias de supervisão e do Comité Europeu do Risco Sistémico. Assim, nos termos do art. $^{\circ}$ 5. ${ }^{\circ}$, n. $^{\circ}$ 1, do Regulamento n. ${ }^{\circ}$ 1092/2010, o Presidente do BCE preside ao Comité Europeu do Risco Sistémico; de acordo com os artigos 55. ${ }^{\circ},{ }^{\circ} 3$, dos Regulamentos n..$^{\circ} 1093$ / /2010, n. ${ }^{\circ} 1094 / 2010$ e n. ${ }^{\circ}$ 1095/2010, o Presidente da Auto- 
ridade Bancária Europeia ou o Presidente da Autoridade Europeia dos Seguros e Pensões Complementares de Reforma ou o Presidente da Autoridade Europeia dos Valores Mobiliários e dos Mercados preside, anualmente e de forma rotativa, ao Comité Conjunto das Autoridades Europeias de Supervisão; finalmente, por força do art. ${ }^{\circ} 5 .^{\circ}$, n. $^{\circ} 3$, do Regulamento n. ${ }^{\circ}$ 1092/2010, e dos artigos 55. ${ }^{\circ},{ }^{\circ} .^{\circ} 3$, dos Regulamentos n. ${ }^{\circ} 1093 / 2010$, n. $^{\circ} 1094 / 2010$ e n. ${ }^{\circ} 1095 / 2010$, o Presidente do Comité Conjunto das Autoridades Europeias de Supervisão é vice-presidente do Comité Europeu do Risco Sistémico.

Estas presidências e vice-presidências cruzadas evidenciam a preocupação de aumentar a coordenação supervisora, bem como a ambição de progredir para uma harmonização decisória. Aliás, o Roteiro para uma união bancária, de 12 de Setembro de 2012, sublinha várias vezes esta ambição, mormente no que concerne à criação do mecanismo único de supervisão para os bancos da área do euro e ao mecanismo único de resolução para o sector bancário.

\section{Em jeito de síntese: o impedimento da fragmenta- ção dos mercados financeiros}

De forma deliberada, fez-se coincidir a apreciação do escopo do «impedimento da fragmentação dos mercados financeiros» com a conclusão deste trabalho, que versa sobre os objectivos da união bancária.

Esta coincidência justifica-se porque os vários objectivos da união bancária revelam um denominador comum, na forma de um temor idêntico: a incipiência da união bancária pode fragmentar os mercados financeiros e perigar a consolidação do mercado interno.

As disposições de política monetária do TFUE e do Protocolo relativo aos Estatutos do Sistema Europeu de Bancos Centrais e 
do Banco Central Europeu subalternizaram a estabilidade do sistema financeiro à estabilidade dos preços. Sublinhe-se, especialmente, que a consagração da União Económica e Monetária não foi acompanhada pela instituição de uma união bancária.

Acresce que a estabilização do sistema financeiro, maxime do sector bancário, só entrou na agenda europeia, após a deflagração da crise de 2007, como tentativa de coordenação entre as actividades de supervisão prudencial das autoridades nacionais e comunitárias, com vista ao reforço da resiliência do mercado financeiro da União Europeia.

O «pacote legislativo de Novembro de 2010» procurou colmatar algumas das lacunas estruturais da União Económica e Monetária, em matéria de coordenação entre as autoridades de supervisão prudencial dos estados-membros e da União Europeia, bem como de coerência intersectorial entre as três novas autoridades europeias de supervisão - a Autoridade Bancária Europeia, a Autoridade Europeia dos Seguros e Pensões Complementares de Reforma e a Autoridade Europeia dos Valores Mobiliários e dos Mercados.

Sublinhe-se que o «pacote legislativo de Novembro de 2010» interligou a supervisão microprudencial dos sectores bancário, segurador e dos valores mobiliários, com a supervisão macroprudencial, assegurada pelo Comité Europeu do Risco Sistémico, ao qual é confiada a missão primordial de combate ao «efeito de contágio».

A evitação do «efeito de contágio» contribuiria para a salvaguarda da estabilidade do sistema financeiro, considerada como condição sine qua non para o funcionamento regular do mercado interno, pelo Regulamento que cria o Comité Europeu do Risco Sistémico. Destarte, a evolução do mercado interno seria indissociável da estabilidade do sistema financeiro, mormente da solidez do sector bancário.

No mesmo sentido, o Roteiro para uma união bancária, apresentado em 12 de Setembro de 2012, alerta para as con- 
sequências disruptivas sistémicas das falências bancárias sobre a economia real.

No intuito de travar a deflagração de "corridas bancárias» e de impedir o constrangimento ao crédito público e privado, as autoridades de vários estados-membros organizaram operações de resgate às instituições de crédito ameaçadas. Porém, apesar de as consequências sistémicas da insolvência ou da falência de um banco não ficarem confinadas às fronteiras do país de origem, sobretudo dos que partilham a mesma moeda, a União Europeia revelou a ausência de um quadro integrado de gestão de crises.

Tal ausência evidencia que a segurança dos depositantes não depende apenas dos indicadores específicos dos respectivos depositários, mas também da rede de protecção, que as autoridades nacionais estejam dispostas a organizar e a financiar. Assim, não obstante a passagem para a 3. ${ }^{a}$ fase da UEM, a opção dos depositantes é condicionada pela maior ou menor probabilidade de os depositários serem resgatados pelas autoridades nacionais, em caso de deflagração de uma corrida bancária, o que suscita a fragmentação dos mercados financeiros.

Sublinhe-se que as opções dos depositantes são igualmente condicionadas pelas divergências entre os sistemas de garantia de depósitos dos diferentes estados-membros. Apesar das aproximações legislativas já encetadas, os países participantes da 3. ${ }^{\text {a }}$ fase da UEM continuam sem um SGD comum. Destarte, a livre circulação de capitais e a ausência de risco cambial não são suficientes para criarem um mercado bancário único.

Acresce que a apreciação das instituições de crédito pelos operadores internacionais, maxime pelas agências de rating, não dissocia a avaliação das emissões de dívida bancária das notações de dívida soberana, isto é, o sovereign rating condiciona o corporate rating. Logo, a inexistência de um mercado de dívida soberana único enviesa a comparabilidade entre as notações atribuídas às instituições de crédito de diferentes estados- 
-membros, o que também contribui para a fragmentação dos mercados bancários.

A indissociabilidade entre o sovereign rating e o corporate rating transparece ainda no financiamento público das operações de bailout. $\mathrm{Na}$ ausência de um mecanismo único de resolução, a capacidade de suportar um resgate dependeria do orçamento do estado-membro do banco sob assistência financeira.

Neste sentido, a proposta de criação do «Sistema europeu de dispositivos de resolução bancária e mecanismos de financiamento", sustentado por impostos cobrados às instituições financeiras, atenuaria a fragmentação do sistema bancário.

Além de internalizar os custos das externalidades negativas, a tributação das transacções financeiras contribuiria igualmente para a consolidação orçamental dos estados-membros, através do aumento das receitas públicas, e para o combate à arbitragem fiscal, através da aplicação de normas tributárias comuns.

A instituição de um sistema comum de imposto sobre as transacções financeiras convergiria para a estabilização do sistema financeiro e, por força da crescente «financeirização» da actividade económica, para a preservação do próprio mercado interno.

Por último, sublinhe-se que a várias propostas, apresentadas em Novembro de 2010 e reafirmadas em Setembro de 2012, evidenciam a importância da coordenação entre as autoridades de supervisão nacionais e europeias, bem como da partilha de informações e da definição, monitorização e avaliação de «painéis de riscos», e apontam no sentido do progresso da coordenação supervisora para a harmonização decisória, mormente graças à instituição do Comité Conjunto das Autoridades Europeias de Supervisão. 


\section{REFERÊNCIAS BIBLIOGRÁFICAS}

Aghion, Philippe, Bolton, Patrick; Dewatripont, Mathias (2000): "Contagious Bank Failures in a Free Banking System", em European Economic Review, Vol. 44, n. ${ }^{\circ}$ 4-6, pp. 713-718.

Alten, Franklin; Herring, Richard J. (2001): "Banking Regulation versus Securities Market Regulation", Center for Financial Institutions Working Papers, n. ${ }^{\circ}$ 01-29, Julho, Filadélfia, Wharton School Center for Financial Institutions, University of Pennsylvania, $55 \mathrm{pp}$.

Allen, Franklin; Song, Wei Ling (2005): "Financial Integration and EMU”, em European Financial Management, Vol. 11, n. ${ }^{\circ}$ 1, pp. 7-24.

Angbazo, Lazarus; Saunders, Anthony (1997): "The Effect of TBTF Deregulation on Bank Cost of Funds", Center for Financial Institutions Working Papers, n. ${ }^{\circ}$ 97-25, Maio, Filadélfia, Wharton School Center for Financial Institutions, University of Pennsylvania, 42 pp.

Avelãs Nunes, António José (2012): A crise do Capitalismo: Capitalismo, Neoliberalismo, Globalização, 4. ${ }^{a}$ edição revista, Lisboa, Página a Página.

Bieling, Hans-Jürgen (2006): "EMU, financial integration and global economic governance", em Review of International Political Economy, Vol. 13, n. ${ }^{\circ} 3$, pp. 420-448.

Bikhchandani, Sushil; Sharma, Sunil (2000): "Herd Behavior in Financial Markets - A Review", IMF Working Paper, n. ${ }^{\circ}$ WP/00/48, Março, Washington, International Monetary Fund, $32 \mathrm{pp}$.

Blanchard, Olivier Jean (2002): "Crowding out", em The New Palgrave: A Dictionary of Economics, Vol. 1, reimp. com correcções, org. por Eatwell, John; Milgate, Murray; Newman, Peter, Basingstoke, Palgrave Publishers, pp. 728-730 (1. .a ed., 1987).

Bordo, Michael D., Mizrach, Bruce; Schwartz, Anna J. (1995): "Real versus Pseudo-International Systemic Risk: Lessons from History", NBER Working Papers Series, n. ${ }^{\circ}$ 5371, Dezembro, Cambridge, Massachusetts, National Bureau of Economic Research, 45 pp.

Bordo, Michael D.; Schwartz, Anna J. (1999): "Under What Circumstances, Past and Present, Have International Rescues of Countries in Financial Distress Been Successful?”, em Journal of International Money and Finance, Vol. 18, n. ${ }^{\circ}$ 4, Agosto, pp. 683-708.

Cabo, Sérgio Gonçalves do (2012): “Artigo 124. "”, em Tratado de Lisboa Anotado e Comentado, org. por Porto, Manuel Lopes; Anastácio, Gonçalo, Coimbra, Almedina, pp. 569-572. 
Calomiris, Charles W.; Kahn, Charles M. (1991): “The Role of Demandable Debt in Structuring Optimal Banking Arrangements", em The American Economic Review, Vol. 81, n. ${ }^{\circ}$ 3, Junho, pp. 497-513.

Caprio Jr., Gerard; Klingebiel, Daniela (1996a): "Bank Insolvencies: Cross-Country Experience", Policy Research Working Paper, n. ${ }^{\circ} 1620$, Julho, Washington, The World Bank, Policy Research Department, Finance and Private Sector Development Division, 60 pp. (1996b): "Bank Insolvency: Bad Luck, Bad Policy, or Bad Banking?", comunicação apresentada em World Bank's Annual Conference on Development Economics, org. por The InTERnational Bank for Reconstruction and Development / The World Bank, Washington, 25 e 26 de Abril de 1996, 26 pp. [formato electrónico disponível em: < http://siteresources.worldbank.org/DEC/Resources/18701_bad_luck.pdf $>$.

Cardim de Carvalho, Fernando J. (2002): "Remarks on the Proposal to Create a Sovereign Bankruptcy Court", comunicação apresentada em Alternatives to Neoliberalism Conference sponsored by the New Rules for Global Finance Coalition, Washington, 23 e 24 de Maio, 4 pp. Carletti, Elena (1999): "Bank Moral Hazard and Market Discipline", Discussion Paper, n. ${ }^{\circ}$ 326, Maio, Londres, London School of Economics - Financial Markets Group, 25 pp.

Chang, Ha-Joon; Grabel, Ilene (2004): Reclaiming Development: An Alternative Economic Policy Manual, Londres, Zed Books.

Chang, Roberto; Velasco, Andrés (1998a): "Financial Crises in Emerging Markets: A Canonical Model”, NBER Working Papers Series, n. ${ }^{\circ}$ 6606, Junho, Cambridge, Massachusetts, National Bureau of Economic Research, 45 pp.

— (1998b): "The Asian Liquidity Crisis", NBER Working Papers Series, n. ${ }^{\circ}$ 6796, Novembro, Cambridge, Massachusetts, National Bureau of Economic Research, 59 pp.

Chari, V. V.;Jagannathan, Ravi (1988): "Banking Panics, Information, and Rational Expectations Equilibrium", em The Journal of Finance, Vol. XLIII, n. ${ }^{\circ}$ 3, Julho, pp. 749-761.

Cole, Harold L.; Kehoe, Timothy J. (1998): "Self-Fulfilling Debt Crises", Staff Report, n. ${ }^{\circ}$ 211, Julho, Minneapolis, Federal Reserve Bank of Minneapolis, $41 \mathrm{pp}$.

Comissão Europeia (2010a): Commission Staff Working Document: Financial Sector Taxation, accompanying the Communication from the Commission to the European Parliament, the Council, the European Economic and Social Committee and the Committee of the Regions: Taxation of the Financial Sector, Bruxelas, 07.10.2010, SEC(2010) 1166. 
- (2010b): Comunicação da Comissão ao Parlamento Europeu, ao Conselho, ao Comité Económico e Social Europeu e ao Comité das Regiões: A tributação do sector financeiro, Bruxelas, 07.10.2010, COM(2010) 549 final. - (2010c): Proposta de Directiva .../.../UE do Parlamento Europeu e do Conselho relativa aos sistemas de garantia de depósitos [reformulação], Bruxelas, 12.07.2010, COM(2010) 368 final - 2010/0207 (COD).

- (2011a): Proposta alterada de Decisão do Conselho relativa ao sistema de recursos próprios da União Europeia (.../.../CE, Euratom), Bruxelas, 09.11.2011, COM(2011) 739 final - 2011/0183 (CNS).

- (2011b): Proposta de Decisão do Conselho relativa ao sistema de recursos próprios da União Europeia (.../.../CE, Euratom), Bruxelas, 29.06.2011, COM(2011) 510 final - 2011/0183 (CNS).

- (2011c): Proposta de Directiva do Conselho sobre um sistema comum de imposto sobre as transacções financeiras e que altera a Directiva 2008/7/CE, Bruxelas, 28.09.2011, COM(2011) 594 final - 2011/0261 (CNS).

- (2011d): Proposta de Regulamento do Conselho relativo aos métodos e ao procedimento para a colocação à disposição do recurso próprio baseado no imposto sobre as transacções financeiras, Bruxelas, 09.11.2011, COM(2011) 738 final - 2011/0334 (CNS).

- (2012a): Comunicação da Comissão ao Parlamento Europeu e ao Conselho: roteiro para uma união bancária, Bruxelas, 12.9.2012, COM(2012) 510 final.

- (2012b): Proposta de Directiva do Parlamento Europeu e do Conselho que estabelece um enquadramento para a recuperação e resolução de instituições de crédito e empresas de investimento e que altera as Diretivas 77/91/CEE e 82/891/CE do Conselho, as Diretivas 2001/24/CE, 2004/47/CE, 2004/25/CE, 2005/56/CE, 2007/36/CE e 2011/55/CE e o Regulamento (UE) n. ${ }^{\circ}$ 1093/2010, Bruxelas, 06.06.2012, COM(2012) 280 final - 2012/0150 (COD).

- (2012c): Proposta de Regulamento do Conselho que confere ao BCE atribuições específicas no que diz respeito às políticas relativas à supervisão prudencial das instituições de crédito, Bruxelas, 12.9.2012, COM(2012) 511 final - 2012/0242 (CNS).

- (2012d): Proposta de Regulamento do Parlamento Europeu e do Conselho que altera o Regulamento (UE) n. ${ }^{\circ} 1093 / 2010$ que cria uma Autoridade Europeia de Supervisão (Autoridade Bancária Europeia) no que respeita à sua interacção com o Regulamento (UE) $n .^{\circ}$... / . . do Conselho que confere ao Banco Central Europeu atribuiçooes específicas no que diz respeito às políticas relativas à supervisão prudencial das instituições de crédito, Bruxelas, 12.9.2012, COM(2012) 512 final - 2012/0244 (COD). 
Corsetti, Giancarlo; Pesenti, Paolo; Roubini, Nouriel (1998): “Paper Tigers? A Model of the Asian Crisis", NBER Working Papers Series, n. ${ }^{\circ}$ 6783, Novembro, Cambridge, Massachusetts, National Bureau of Economic Research, 43 pp.

Cunha, Patrícia Noiret (2012): "Artigo 113.", em Tratado de Lisboa Anotado e Comentado, org. por Porto, Manuel Lopes; Anastácio, Gonçalo, Coimbra, Almedina, pp. 536-538.

Davis, E. Philip (2003): "Institutional Investors, Financial Market Efficiency and Financial Stability", Discussion Paper, n. ${ }^{\circ}$ PI-0303, Janeiro, Londres, The Pensions Institute, Birkbeck College, University of London, $44 \mathrm{pp}$.

De Bandt, Olivier (1995): “Competition Among Financial Intermediaries and the Risk of Contagious Failures" (versão original, 1994), Notes d' Etudes et de Recherche, n. ${ }^{\circ}$ 30, Paris, Banque de France, Direction des Études Économiques et de la Recherche, 47 pp.

De Bandt, Olivier; Hartmann, Philipp (2002): "Systemic Risk in Banking: A Survey", em Financial Crises, Contagion, and the Lender of Last Resort: A Reader, org. por Charles Goodhart e Gerhard Illing, Oxford, Oxford University Press, pp. 249-297.

Devenow, Andrea; Welch, Ivo (1996): "Rational Herding in Financial Economics", em European Economic Review, Vol. 40, n. ${ }^{\circ} 3-5$, Abril, pp. 603-615.

Diamond, Douglas W.; Dybvig,Philip H. (1983): "Bank Runs, Deposit Insurance, and Liquidity", em Journal of Political Economy, Vol. 91, n. ${ }^{\circ}$, pp. 401-419.

Diamond, Douglas W.; Rajan, Raghuram G. (1999a): “A Theory of Bank Capital”, NBER Working Papers Series, n. ${ }^{\circ}$ 7431, Dezembro, Cambridge, Massachusetts, National Bureau of Economic Research, $56 \mathrm{pp}$.

- (1999b): "Liquidity Risk, Liquidity Creation and Financial Fragility: A Theory of Banking", NBER Working Papers Series, n. ${ }^{\circ} 7430$, Dezembro, Cambridge, Massachusetts, National Bureau of Economic Research, 53 pp.

- (2000): "Banks, Short Term Debt and Financial Crises: Theory, Policy Implications and Applications”, NBER Working Papers Series, n. ${ }^{\circ} 7764$, Junho, Cambridge, Massachusetts, National Bureau of Economic Research, 39 pp.

- (2002): "Liquidity Shortages and Banking Crises", NBER Working Papers Series, n. ${ }^{\circ}$ 8937, Maio, Cambridge, Massachusetts, National Bureau of Economic Research, 53 pp. 
Drazen, Allan; Masson, Paul R. (1994): “Credibility of Policies versus Credibility of Policymakers", em The Quarterly Journal of Economics, Vol. 119, n. ${ }^{\circ} 3$, Agosto, pp. 735-754.

Fitzgibbons, Athol (1990): Keynes's Vision: A New Political Economy, reimp., Nova Iorque, Clarendon Press - Oxford University Press (1. ${ }^{a}$ ed., 1988).

Flood, Robert P.; Garber, Peter M. (1984): “Collapsing Exchange-Rate Regimes: Some Linear Examples”, em Journal of International Economics, Vol. 17, n. ${ }^{\circ}$ 47, Agosto, pp. 1-13.

Freixas, Xavier (1999): “Optimal Bail-Out, Conditionality and Creative Ambiguity”, CEPR Discussion Papers, n. ${ }^{\circ}$ 2238, Setembro, Londres, Centre for Economic Policy Research, 31 pp.

Freixas, Xavier; PArigi, Bruno M.; Rochet, Jean-Charles (2000): "Systemic Risk, Interbank Relations, and Liquidity Provision by the Central Bank", em Journal of Money, Credit and Banking, Vol. 32, n. ${ }^{\circ}$ 3, Agosto, pp. 611-638.

FreiXas, Xavier; Rochet, Jean-Charles (1998): Microeconomics of Banking, reimp., Cambridge, Massachusetts, The MIT Press (1. ${ }^{\mathrm{a}}$ ed., 1997).

Furfine, Craig (2002): “The Costs and Benefits of Moral Suasion: Evidence from the Rescue of Long-Term Capital Management", Working Paper Series, n. ${ }^{\circ}$ WP-02-11, Chicago, Federal Reserve Bank of Chicago, 37 pp.

Garber, Peter M.; Grilli, Vittorio U. (1988): “Bank Runs in Open Economies and the International Transmission of Panics", NBER Working Papers Series, n. ${ }^{\circ}$ 2764, Novembro, Cambridge, Massachusetts, National Bureau of Economic Research, 18 pp.

Goodhart, Charles; Illing, Gerhard (2002): "Introduction", em Financial Crises, Contagion, and the Lender of Last Resort: A Reader, org. por Goodhart, Charles; Illing, Gerhard, Oxford, Oxford University Press, pp. 1-26.

Gorton, Gary (1985): "Bank Suspension of Convertibility”, em Journal of Monetary Economics, n. ${ }^{\circ}$ 15, pp. 177-193.

Grabel, Ilene (1995): "Speculation-Led Economic Development: A Post-Keynesian Interpretation of Financial Liberalization Programmes in the Third World", em International Review of Applied Economics, Vol. 9, n. ${ }^{\circ}$ 2, pp. 127-149.

- (2002): "Neoliberal Finance and Crisis in the Developing World", em Monthly Review: An Independent Socialist Magazine, Vol. 53, n. ${ }^{\circ} 11$, Abril, pp. 34-46. 
- (2003a): “Averting Crisis? Assessing Measures to Manage Financial Integration in Emerging Economies", em Cambridge Journal of Eco-

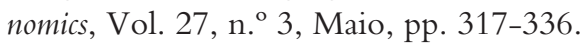

— (2003b): "Predicting Financial Crisis in Developing Economies: Astronomy or Astrology?", em Eastern Economics Journal, Vol. 29, n. ${ }^{\circ}$ 2, Primavera, pp. 243-258.

Guenther, Kenneth A. (2001): "Community Bankers, Deposit Insurance Reform and Too Big To Fail", em Proceedings from Federal Reserve Bank of Chicago, Maio, pp. 32-38.

Jacklin, Charles J.; Bhattacharya, Sudipto (1988): "Distinguishing Panics and Information-based Bank Runs: Welfare and Policy Implications", em Journal of Political Economy, Vol. 96, n. ${ }^{\circ}$ 3, Junho, pp. 568-592.

Jeanne, Olivier (1997): “Are Currency Crises Self-fulfilling?: A Test”, em Journal of International Economics, Vol. 43, n. ${ }^{\circ} 3-4$, Novembro, pp. $263-$ -286 .

Kahneman, Daniel (2002): "New Challenges to the Rationality Assumptions" (publicação original, 1994), em Choices, Values and Frames, reimp., org. por Kahneman, Daniel; Tversky, Amos, Cambridge, Cambridge University Press, pp. 758-774 (1. a ed., 2000).

Kahneman, Daniel; Knetsch; Jack L.; Thaler; Richard H. (1987): "Fairness and the Assumptions of Economics", em Rational Choice: The Contrast Between Economics and Psychology, org. por Hogarth, Robin M.; Reder, Melvin W., Chicago, The University of Chicago Press, pp. 101-116.

— (2002): "Fairness as a Constraint on Profit Seeking: Entitlements in the Market" (publicação original, 1986), em Choices, Values and Frames, reimp., org. por Kahneman, Daniel; Tversky, Amos, Cambridge, Cambridge University Press, pp. 317-334 (1. a ed., 2000).

Kahneman, Daniel; Ritov, Ilana; Schkade, David (2002): "Economic Preferences or Attitude Expressions? An Analysis of Dollar Responses to Public Issues" (publicação original, 1999), em Choices, Values and Frames, reimp., org. por Kahneman, Daniel; Tversky, Amos,

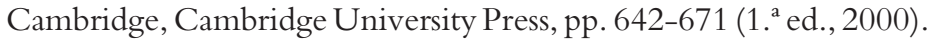

Kahneman, Daniel; Tversky, Amos, (2002a): "Choices, Values and Frames" (publicação original, 1984), em Choices, Values and Frames, reimp., org. por Kahneman, Daniel; Tversky, Amos, Cambridge, Cambridge University Press, pp. 1-16 (1. a ed., 2000).

- (2002b): "Prospect Theory: An Analysis of Decision Under Risk" (publicação original, 1979), em Choices, Values and Frames, reimp., 
org. por Kahneman, Daniel; Tversky, Amos, Cambridge, Cambridge University Press, pp. 17-43 (1. a ed., 2000).

Kaminsky, Graciela L.; Reinhart, Carmen M. (2000): “On Crises, Contagion, and Confusion", em Journal of International Economics, Vol. 51, n. ${ }^{\circ}$ 1, Junho, pp. 145-168.

KANE, Edward J. (2002): “Dynamic Inconsistency of Capital Forbearance: Long-Run Versus Short-Run Effects of Too-Big-to-Fail Policy-making”, em Financial Risks, Stability, and Globalization, org. por Johnson, Omotunde E. G., Washington, International Monetary Fund, pp. 320-339.

Kaufman, George G. (2003a): “A Proposal for Efficiently Resolving Out-of-the-Money Swap Positions at Large Insolvent Banks", Working Paper Series, n. ${ }^{\circ}$ WP-03-01, Janeiro, Chicago, Federal Reserve Bank of Chicago, 19 pp.

- (2003b): "Depositor Liquidity and Loss-Sharing in Bank Failure Resolutions", Working Paper Series, n. ${ }^{\circ}$ WP-03-02, Janeiro, Chicago, Federal Reserve Bank of Chicago, 24 pp.

Kaufman, George G.; Seelig, Steven A. (2001): "Post-Resolution Treatment of Depositors at Failed Banks: Implications for the Severity of Banking Crises, Systemic Risk, and Too-Big-To-Fail”, IMF Working Paper, n. ${ }^{\circ} \mathrm{WP} / 01 / 83$, Junho, Washington, International Monetary Fund, 22 pp.

Keynes, John Maynard (1973): The General Theory of Employment, Interest, and Money, em The Collected Writings of John Maynard Keynes, Vol. VII, org. por The Royal Economic Society, Londres, Macmillan (1. a ed., 1936).

Kodres, Laura E.; Pritsker, Matthew (2002): “A Rational Expectations Model of Financial Contagion”, em The Journal of Finance, Vol. 57, n. ${ }^{\circ}$ 2, Abril, pp. 769-799.

Krugman, Paul (1979): “A Model of Balance-of-Payments Crises”, em Journal of Money, Credit and Banking, Vol. 11, n. ${ }^{\circ} 3$, Agosto, pp. 311-325 .

— (1996): “Are Currency Crises Self-Fulfilling?”, em NBER Macroeconomics Annual, Vol. 11, org. por Bernanke, Ben S.; Rotemberg, Julio J. Cambridge, Massachusetts, The MIT Press, pp. 345-407.

- (1998): "What Happened to Asia?", Janeiro, 8 pp. [formato electrónico disponível em: < http://web.mit.edu/krugman/www/ DISINTER.html >.

— (1999): "Currency Crises", em International Capital Flows - A National Bureau of Economic Research Conference Report, org. por FeldSTEIn, 
Martin, Chicago, The University of Chicago Press, pp. 421-440 .

— (2003): “Crisis: The Next Generation?”, em Economic Policy in the International Economy: Essays in Honor of Assaf Razin, org. por HeLPMAN, Elhanan; SAdka, Efraim, Cambridge, Cambridge University Press, pp. 15-32.

LANe, Philip R. (2008): “EMU and Financial Integration”, IIIS Discussion Paper, n. ${ }^{\circ}$ 272, Dezembro, Dublin, Institute for International Integration Studies, $42 \mathrm{pp}$.

Liıkanen, Erkki [Presidente]; Bänziger, Hugo; Campa, José Manuel; Gallois, Louis; Goyens, Monique; Krahnen, Jan Pieter; MazzucChelli, Marco; Sergeant, Carol; Tuma, Zdenek; Vanhevel, Jan; WijfFels, Herman, Orgs. (2012): High-level Expert Group on reforming the structure of the EU banking sector - final report, Bruxelas, 2 de Outubro de 2012.

Lindgren, Carl-Johan, Garcia, Gillian; SaAl, Matthew I. (1996): Bank Soundness and Macroeconomic Policy, Washington, International Monetary Fund.

Machado, Pedro (2012): “Artigo 123. ${ }^{\circ}$ ", em Tratado de Lisboa Anotado e Comentado, org. por Porto, Manuel Lopes; Anastácio, Gonçalo, Coimbra, Almedina, pp. 565-568.

Masson, Paul R. (1995): "Gaining and Losing ERM Credibility: The Case of the United Kingdom", em The Economic Journal, Vol. 105, n. ${ }^{\circ}$ 430, Maio, pp. 571-582.

— (1999): "Contagion: Macroeconomic Models with Multiple Equilibria", em Journal of International Money and Finance, Vol. 18, n. ${ }^{\circ} 4$, Agosto, pp. 587-602.

Mota, Júlio; Lopes, Luís Peres; Antunes, Margarida, Orgs. (2010): Financeirização da Economia: A última fase do neoliberalismo, Lisboa, Livre.

Obstfeld, Maurice (1991): "Destabilizing Effects of Exchange-Rate Escape Clauses", NBER Working Papers Series, n. ${ }^{\circ}$ 3603, Janeiro, Cambridge, Massachusetts, National Bureau of Economic Research, 29 pp.

- (1994): "The Logic of Currency Crises", em Banque de France Cahiers Economiques et Monetaires, Vol. 43, pp. 189-213.

— (1996): "Models of Currency Crises with Self-Fulfilling Features", em

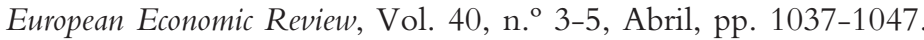

Ozkan, F. Gulcin; Sutherland, Alan (1995): "Policy Measures to Avoid a Currency Crisis", em The Economic Journal, Vol. 105, n. ${ }^{\circ} 429$, Março, pp. 510-519. 
- (1998): "A Currency Crisis Model with an Optimising Policymaker”, em Journal of International Economics, Vol. 44, n. ${ }^{\circ}$ 2, Abril, pp. 339-364.

Palma, Clotilde Celorico (2012): “Artigo 111. ", em Tratado de Lisboa Anotado e Comentado, org. por Porto, Manuel Lopes; Anastácio, Gonçalo, Coimbra, Almedina, pp. 531-533.

Quelhas, José Manuel (1996): Sobre a evolução recente do sistema financeiro (Novos "produtos financeiros»), Coimbra, Separata do Boletim de Ciências Económicas da Faculdade de Direito da Universidade de Coimbra, distribuição da Livraria Almedina.

— (2012a): "Sobre a criação do Comité Europeu de Risco Sistémico", em Estudos em Homenagem ao Prof. Doutor Aníbal Almeida, org. por Avelãs Nunes, António José; Cunha, Luís Pedro; Martins, Maria Inês de Oliveira, Coimbra, Boletim da Faculdade de Direito, Studia Iuridica, 107, Ad Honorem, 7, Coimbra Editora, pp. 877-899.

- (2012b): Sobre as crises financeiras, o risco sistémico e a incerteza sistemática, Coimbra, Almedina.

Radelet, Steven; Sachs, Jeffrey (1998a): “The East Asian Financial Crisis: Diagnosis, Remedies, Prospects", Brookings Papers on Economic Activity, n. ${ }^{\circ}$ 1998/1, Abril, Washington, The Brookings Institution, 74 pp.

- (1998b): "The Onset of the East Asian Financial Crisis", NBER Working Papers Series, n. ${ }^{\circ}$ 6680, Agosto, Cambridge, Massachusetts, National Bureau of Economic Research, 79 pp.

Rosser Jr., J. Barkley (2000): "Self-Fulfilling Chaotic Mistakes: Some Examples and Implications", em Discrete Dynamics in Nature and Society, Vol. 4, n. ${ }^{\circ}$ 1, pp. 29-37.

Scharfstein, David S.; Stein, Jeremy (1990): "Herd Behaviour and Investment", em The American Economic Review, Vol. 80, n. ${ }^{\circ} 3$, Junho, pp. 465-479.

Schwartz, Anna J. (1998): “Coping with Financial Fragility: A Global Perspective", em Coping with Financial Fragility and Systemic Risk, reimp., org. por Benink, Harald A., Dordrecht, Kluwer Academic

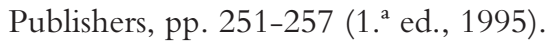

Shiller, Robert J. (1993): "Stock Prices and Social Dynamics" (publicação original, 1984), em Advances in Behavioral Finance, org. por Thaler, Richard H., Nova Iorque, The Russell Sage Foundation, pp. 167-217.

- (1995): "Conversation, Information, and Herd Behavior", Cowles Foundation Discussion Papers, n. ${ }^{\circ}$ 1092, Janeiro, New Haven, Cowles Foundation, Yale University, $13 \mathrm{pp}$. 
- (2001): Irrational Exuberance, reimp., Princeton, Princeton University Press (1. ${ }^{a}$ ed., 2000).

- (2003): The New Financial Order: Risk in the 21 $1^{\text {st }}$ Century, Princeton, Princeton University Press.

Skidelsky, Robert (2000): “Two Stories of Investment: Risk Versus Uncertainty", em Financial Crises, org. por The Social Market Foundation - The Centre for Post-Collectivist Studies, Londres, Profile Books, pp. 1-18.

Smith, Bruce D. (1991): "Bank Panics, Suspension and Geography: Some Notes on the 'Contagion of Fear' in Banking", em Economic Inquiry, Vol. XXIX, Abril, pp. 230-248.

Spiegel, Mark M. (2009a): "Monetary and Financial Integration in the EMU: Push or Pull?”, em Review of International Economics, Vol. 17, n. ${ }^{\circ} 4$, pp. 751-776.

- (2009b): "Monetary and financial integration: Evidence from the EMU”, em Journal of The Japanese and International Economies, Vol. 23, n. ${ }^{\circ}$ 2, Junho, pp. 114-130.

Spiegel, Mark M.; Yamori, Nobuyoshi (2000): "The Evolution of "Too-Big-to-Fail" Policy in Japan: Evidence from Market Equity Values", Pacific Basin Working Paper Series, n. ${ }^{\circ}$ 00-01, Abril, São Francisco, Federal Reserve Bank of San Francisco, 32 pp.

Temzelides, Theodosios (1997): "Evolution, Coordination and Banking Panics”, em Journal of Monetary Economics, n. ${ }^{\circ} 40$, pp. 163-183.

Tversky, Amos; Kahneman, Daniel (2002): "Rational Choice and the Framing of Decisions" (publicação original, 1986), em Choices, Values and Frames, reimp., org. por Kahneman, Daniel; Tversky, Amos, Cambridge, Cambridge University Press, pp. 209-223 (1. ed., 2000).

Waldo, Douglas G. (1985): "Bank Runs, the Deposit-Currency Ratio and the Interest Rate", em Journal of Monetary Economics, n. ${ }^{\circ}$ 15, pp. 269-277.

YuAn, Kathy (2005): "Asymmetric Price Movements and Borrowing Constraints: A Rational Expectations Equilibrium Model of Crisis, Contagion, and Confusion", em The Journal of Finance, Vol. LX, n. ${ }^{\circ} 1$, Fevereiro, pp. 379-411. 
Resumo: O artigo examina os objectivos primordiais da criação da união bancária, a saber: $i$ ) o reforço da resiliência do sistema financeiro; ii) a evitação do "efeito de contágio»; iii) a destrinça entre a evolução da dívida soberana e a evolução da dívida bancária; iv) a contenção do financiamento público das operações de bailout; $v$ ) o progresso da coordenação supervisora para a harmonização decisória; vi) o impedimento da fragmentação dos mercados financeiros.

Os vários objectivos revelam um denominador comum, na forma de um temor idêntico: a incipiência da união bancária pode fragmentar os mercados financeiros e perigar a consolidação do mercado interno.

A referida incipiência da união bancária revela-se nas seguintes fragilidades:

- a consagração da União Económica e Monetária não foi acompanhada pela instituição de uma união bancária;

- após a deflagração da crise de 2007, a União Europeia revelou a ausência de um quadro integrado de gestão de crises;

- a segurança dos depositantes não depende apenas dos indicadores específicos dos respectivos depositários, mas também da rede de protecção, que as autoridades nacionais estejam dispostas a organizar e a financiar;

- não obstante a passagem para a 3. ${ }^{\text { }}$ fase da UEM, a opção dos depositantes é condicionada pela maior ou menor probabilidade de os depositários serem resgatados pelas autoridades nacionais, em caso de deflagração de uma corrida bancária;

- as opções dos depositantes são igualmente condicionadas pelas divergências entre os sistemas de garantia de depósitos dos diferentes estados-membros. Apesar das aproximações legislativas já encetadas, os países participantes da 3. ${ }^{\text {a }}$ fase da UEM continuam sem um SGD comum.

- a inexistência de um mercado de dívida soberana único enviesa a comparabilidade entre as notações atribuídas às instituições de crédito de diferentes estados-membros.

Apesar das fragilidades apontadas, o "pacote legislativo", de 24 de Novembro de 2010, e o Roteiro para uma união bancária, de 12 de Setembro de 2012, deram passos decisivos para a preparação da união bancária, através da instituição do Sistema Europeu de Supervisão Financeira, do Comité Europeu do Risco Sistémico, da Autoridade Bancária Europeia, da Autoridade Europeia dos Seguros e Pensões Complementares de Reforma, da Autoridade Europeia dos Valores Mobiliários e dos Mercados e do Comité Conjunto das Autoridades Europeias de Supervisão.

Palavras-chave: união bancária; mecanismo único de supervisão; sistema comum de garantias de depósitos; quadro integrado de gestão de crises; sistema comum de imposto sobre as transacções financeiras. 
On the objectives of the banking union

Abstract: The article examines the main objectives of the creation of banking union, namely: $i$ ) the strengthening of the financial system resilience; ii) the avoidance of the contagion effect, iii) the distinction between the evolution of sovereign debt and banking debt; $i v$ ) the containment of public financing of bailouts; $v$ ) the progress from the supervisory coordination to the decisional harmonization; vi) the prevention of financial markets fragmentation.

Under the guise of a similar fear, the different objectives reveal a common denominator: the incipiency of the banking union may fragment the financial markets and threaten the consolidation of the internal market. The incipiency of the referred banking union is revealed in the following weaknesses:

- the establishment of Economic and Monetary Union was not accompanied by the establishment of a banking union;

- after the deflagration of the 2007 crisis, the European Union has revealed the absence of an integrated crisis management framework;

- the safety of depositors is dependent not only on the specific indicators of the depositories, but also on the protection network that national authorities are willing to organize and finance;

- notwithstanding the passage to the third phase of EMU, the depositors' choice is conditioned by the greater or lesser likelihood of the depositories being rescued by the national authorities, in case of the outbreak of a bank run;

- the depositors' choices are also conditioned by the discrepancies between the deposit guarantee schemes of the different member states. Although legislative approaches have already been undertaken, Members States which have joined the third stage of EMU remain without a common DGS.

- the lack of a single sovereign debt market distorts comparability between the credit institutions' ratings of different Member States.

Despite the weaknesses pointed out above, both the November $24^{\text {th }}$ 2010 «legislative package» and the September 12th 2012 A Roadmap towards a Banking Union have taken decisive steps to prepare the banking union through the institution of the European System of Financial Supervision, the European Systemic Risk Board, the European Banking Authority, the European Insurance and Occupational Pensions Authority, the European Securities and Markets Authority and the Joint Committee of the European Supervisory Authorities.

Keywords: banking union; single supervisory mechanism; common system for deposit guarantees; integrated crisis management framework; common system of financial transaction tax.

José Manuel Quelhas

Faculdade de Direito da Universidade de Coimbra 